$$
\text { DOE/AL/200090-TI }
$$

\title{
SOUTHWEST REGION EXPERIMENT STATION 1988 REPORT
}

DOE/AL/20090--TI

DE91 006933

Prepared for

U.S. Department of Energy

Albuquerque Operations Office

P.O. Box 5400

Albuquerque, New Mexico 87115

Prepared by

Southwest Technology Development Institute

P.O. Box $30001 / 3$ SOL

Las Cruces, New Mexico 88003-0001

May 1989 


\section{TABLE OF CONTENTS}

1.0 INTRODUCTION 1

2.0 TASK 1: SWRES GRID-CONNECTED SYSTEMS PERFORMANCE 7

2.1 TriSolarCorp System $\quad 8$

2.2 Solarex System 9

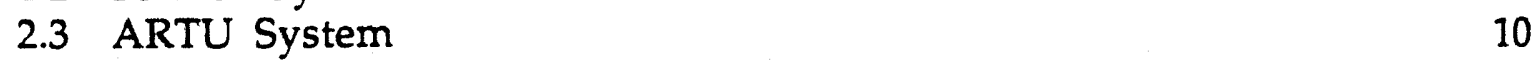

2.4 Westinghouse System 10

$\begin{array}{ll}2.5 \text { Mobil Solar System } & 10\end{array}$

3.0 TASK 2: ON-SITE EVALUATION OF PV SYSTEMS 11

3.1 Newman Power Station System $\quad 12$

3.2 Philadelphia Electric Company (PEC) 13

3.3 Georgetown University System 14

$\begin{array}{ll}3.4 \text { Puerto Rico } & 15\end{array}$

4.0 TASK 3: REMOTE FIELD SITE DATA ACQUISITION 17

5.0 TASK 4: SYSTEM ANALYSIS 17

5.1 Effects of Failures and Maintenance on PV System Performance $\quad 17$

5.2 Structured Testing at the SWRES 19

5.2.1 Chronar II 19

5.2.2 Sovonics R-100 19

$\begin{array}{ll}\text { 5.2.3 Solarex SA-20 System } & 19\end{array}$

5.2.4 Sovonics Power Plus 23

5.2.5 Sovonics Power Plus II 23

5.3 Lighting of SWRES Sign 26

6.0 TASK 6: TECHNOLOGY TRANSFER 26

6.1 Centennial Days 27

6.2 Antique Farm Equipment Show 28

6.3 IEEE Booth 28

6.4 Papers and Reviews $\quad 29$

6.5 DOE Project Review 29

\begin{tabular}{ll}
7.0 & OTHER SWRES PROJECTS \\
\hline
\end{tabular}

7.1 G.R.A.D. Balloon Project 29

7.2 PVUSA Data Acquisition System 31

7.3 TDI/GNERI Joint Venture 32

7.4 Point Design Handbook 33

7.5 Data Acquisition System Design Manual 33 


\section{LIST OF FIGURES}

Figure

Page

1 Cover Sheet of the Stand-Alone Handbook

21988 Horizontal Insolation Comparison with El Paso TMY 7

3 DC Energy Production Comparison for 1987 and $1988 \quad 8$

4 TriSolar System DC Energy Production 18

5 Cumulative Solarex System DC Energy Production 9

6 ARTU System DC Energy Production 10

7 WST System DC Energy Production 11

8 MSEC System DC Energy Production 11

9 Newman Power Station System 13

10 Philadelphia Electric Test Facility near Limerick, Pennsylvania 14

11 Georgetown University System 15

12 Juana Diaz PV System in Puerto Rico 16

13 Value of Maintenance vs. Maintenance Interval 18

14 Chronar II Normalized Power 20

15 Sovonics R-100 Normalized Power vs. Time 21

16 Solarex Normalized Power vs. Time $\quad 22$

17 I-V Curve for Sovonics P101 Array $\quad 24$

18 I-V Curve for Sovonics P102 Array $\quad 25$

19 Lighted SWRES Sign $\quad 26$

20 Solarfest $\quad 27$

21 SWRES Booth at PV Specialist Conference $\quad 28$

22 PV Power Supply for Balloon $\quad 30$

23 Basic System Configuration 31

\section{LIST OF TABLES}

Table

1 Systems Evaluated in $1988 \quad 2$

2 SWRES System Characteristics 6

\section{DISCLAIMER}

This report was prepared as an account of work sponsored by an agency of the United States Government. Neither the United States Governnent nor any agency thereof, $n$ any of their employees, makes any warranty, express or implied, or assumes any legal liability or responsibility for the accuracy, completeness, or usefulness of any information, apparatus, product, or process disclosed, or represents that its use would not infringe privately owned rit is. Reference herein to any specific commercial product, process, or service by trade name, trademark. manufacturer, or otherwise does not necessarily constitute or imply its endorsement, recommendation, or favoring by the United States Government or any agency thereof. The views and opinions of authors expressed herein do not necessarily state or reflect those of the United States Government or any' agency thereof. 


\subsection{INTRODUCTION}

The highlights of asks performed during 1988 by staff members at the Southwest Region Experiment Station (SWRES) are summarized in this report. During 1988, our staff tested and evaluated photovoltaic systems, designed hardware for data acquisition systems, developed software for data analysis, and demonstrated the uses of PV to the public.

Field evaluations of stand-alone and grid-connected systems were a major project for the SWRES in 1988. The goal was to determine the reliability of PV systems, to identify degradation trends, and to recommend solutions to problems. In 1988, the SWRES staff visited 7 sites and tested and evaluated 11 PV systems. Four of the seven tests were paid for under the DOE contract, the balance paid for by private companies or agencies. The sites and the PV systems are listed in table 1.

There were about 7,200 crystalline and 2,200 a-Si modules tested in 1988. Fortyeight crystalline modules were nonproducing; thirty-nine of them in the Georgetown array. Some problems with the a-Si modules were found. However, the significance of these various failures is hard to determine. The failures are hard to categorize because of the differences in this newer technology.

The system ratings determined by the SWRES continue to be lower than the commonly referenced number. Georgetown is the worst example--being rated at 210 $\mathrm{kW}$ compared to the $300 \mathrm{~kW}$ value used to describe the system. Testing results from other systems show system rating 5 to 15 percent below nameplate.

The system testing performed by the SWRES show that module failure rates for crystalline modules is lower than $2 / 10,000$ per year including the high number of failures at Georgetown. For systems that have been operating over seven years, it is still difficult to pinpoint any degradation trend in year to year performance. 
TABLE 1

Systems Evaluated in 1988

\begin{tabular}{|c|c|c|c|}
\hline Site & $\begin{array}{l}\text { Description, Nameplate Rating, } \\
\text { Installation Date }\end{array}$ & Funding Agency & $\begin{array}{c}\text { Rating } \mathrm{kW} \\
\text { Date }\end{array}$ \\
\hline $\begin{array}{l}\text { Juana Diaz, } \\
\text { Puerto Rico }\end{array}$ & $\begin{array}{l}\text { Solarex Flat Plate-100 kW } \\
\text { Polycrystal, } 1987\end{array}$ & Dept. of Ezergy & $\begin{array}{l}90.4 \\
\text { Mar. }\end{array}$ \\
\hline $\begin{array}{l}\text { Georgetown } \\
\text { University }\end{array}$ & $\begin{array}{l}\text { Solarex Flat Plate }-300 \mathrm{~kW} \\
\text { Polycrystal, } 1985\end{array}$ & Dept. of Energy & $\begin{array}{l}210 \\
\text { Jul./Nov }\end{array}$ \\
\hline $\begin{array}{l}\text { Newman Power } \\
\text { Station }\end{array}$ & $\begin{array}{l}\text { Solar Power Flat Plate-20 kW } \\
\text { Single Crystal, } 1981\end{array}$ & Dept. of Energy & $\begin{array}{r}15 \\
\text { Mar. }\end{array}$ \\
\hline $\begin{array}{l}\text { Philadelphia } \\
\text { Electric }\end{array}$ & $\begin{array}{l}\text { Solarex a-Si Flat Plate- } 4 \mathrm{~kW} \\
\mathrm{a}-\mathrm{Si}, 1986\end{array}$ & Dept. of Energy & $\begin{array}{l}3.85 \\
\text { Jul. }\end{array}$ \\
\hline $\begin{array}{l}\text { Florida Power } \\
\text { Corporation }\end{array}$ & $\begin{array}{l}\text { ARCO Flat Plate- } \overline{20 \mathrm{~kW}} \\
\mathrm{a}-\mathrm{Si}, 1988\end{array}$ & $\begin{array}{l}\text { Electric Power } \\
\text { Research Inst. }\end{array}$ & $\begin{array}{c}15 \\
\text { Sept. }\end{array}$ \\
\hline $\begin{array}{l}\text { Systems Operation } \\
\text { Center WP\&L }\end{array}$ & $\begin{array}{l}\text { Sovonics-2 KW } \\
\text { a-Si, } 1987\end{array}$ & $\begin{array}{l}\text { Wisconsin Power } \\
\text { \& Light }\end{array}$ & 1.8 \\
\hline $\begin{array}{l}\text { Barneveld Munic. } \\
\text { Building WP\&L }\end{array}$ & $\begin{array}{l}\text { Mobil Flat Plate-2 KW } \\
\text { Ribbon Silicon, } 1985\end{array}$ & $\begin{array}{l}\text { Wisconsin Power } \\
\text { \& Light }\end{array}$ & $\begin{array}{l}2.04 \\
\text { Jul. }\end{array}$ \\
\hline $\begin{array}{l}\text { Barneveld Res. } \\
\text { WP\&L. }\end{array}$ & $\begin{array}{l}\text { ARCO Flat Plate-2 KW } \\
\text { Single Crystal, } 1985\end{array}$ & $\begin{array}{l}\text { Wisconsin Power } \\
\text { \& Light }\end{array}$ & Jul. $^{1.96}$ \\
\hline $\begin{array}{l}\text { Fond du Lac } \\
\text { WP\&L }\end{array}$ & $\begin{array}{l}\text { ARCO Flat Plate-2 KW } \\
\text { Single Crystal, } 1988\end{array}$ & $\begin{array}{l}\text { Wisconsin Power } \\
\text { \& Light }\end{array}$ & $\begin{array}{l}1.69 \\
\text { Jul. }\end{array}$ \\
\hline $\begin{array}{l}\text { Barneveld Park } \\
\text { Shelter WP\&L }\end{array}$ & $\begin{array}{l}\text { Mobil Flat Plate-2 KW } \\
\text { Ribbon Silicon, } 1986\end{array}$ & $\begin{array}{l}\text { Wisconsin Power } \\
\text { \& Light }\end{array}$ & Jul. \\
\hline Yuma, Arizona & $\begin{array}{l}\text { Photowatt Flat Plate }-4 \mathrm{~kW} \\
\text { Single Crystal, } 1982\end{array}$ & $\begin{array}{l}\text { Arizona Public } \\
\text { Service }\end{array}$ & $\begin{array}{r}3.9 \\
\text { Apr. } \\
\end{array}$ \\
\hline
\end{tabular}

However, there are still reliability problems with switches, fuses, diodes, and protection devices. The PCS causes most of the total energy loss because the entire array is disabled when there is inverter downtime.

Five amorphous systems operated at the SWRES in 1988 along with five crystalline systems. Some modules failures occurred in the Solarex and Sovonics a-Si systems. The I-V curves were taken bi-weekly on the amorphous systems and monthly on the crystalline systems. The data were normalized to $1,000 \mathrm{~W} / \mathrm{m}^{2}$ and $25^{\circ} \mathrm{C}$ using coefficients obtained from the manufacturers or determined by special testing at the SWRES. The performance results are presented in Sections 2.0 and 5.0. 
Hourly performance data from eight off-site photovoltaic systems were collected by computer during 1988; Alabama Power, Hesperia, Dallas-Fort Worth, Detroit, Florida Power, Georgetown University, San Diego, And Virginia Power. The data are collected via modem from Campbell Scientific dataloggers or a Sandia National Laboratory (SNL) designed on-site data acquisition systems (UDAS). The data were tested for validity using quality assurance software developed by TDI and were archived on magnetic tape. These data files are stored at the SWRES in the EPRI and SNL formats. Two of the eight sites, Dallas-Fort Worth Airport and San Diego Gas and Electric's Laguna del Mar are no longer active. The data acquisition system at Laguna del Mar was removed in November 1988 and the data collection computer at Dallas-Fort Worth Airport failed and will not be repaired.

A PV power supply for a balloon borne astronomy experiment was designed, built, and tested. The goal of the experiment was to collect gamma radiation from the Supernova 1987A that was first observed on February 23, 1987. The project was called the G.R.A.D. experiment and was a group project between the University of Florida, the Goddard Space Flight Center, the Air Force Geophysics Laboratory, New Mexico State University, and the Defense Advance Research Projects Agency (DARPA) Nuclear Monitoring Office. The PV power supply provided $750 \mathrm{~W}$ continuously during the four day mission at 120,000 feet over Antarctica in January 1988.

The SWRES supplied the data acquisition system (DAS) for the Photovoltaics for Utility Scale Applications (PVUSA) project, Davis site. A computer and datalogger system including the necessary hardware, software, and documentation for collecting and storing analog and digital data from 8 PV systems (expandable to 22 systems) was designed and delivered. Data are collected at high speed (less than a 5 seconds between samples) and processed automatically. 
Every year significant information about PV is transferred to the public and private sectors through activities of the staff at the SWRES. Guided tours of our facilities were conducted twice each working day for public visitors. Also provided were PV information displays at two local trade shows and a booth at the Twentieth IEEE Photovoltaic Specialists Conference in Las Vegas, Nevada.

Technical presentations were made to DOE management, SNL technical staff, and to EPRI technical staff and membership. A short course presentation on standalone system design was provided at the Twentieth IEEE Photovoltaic Specialists Conference, and five presentations were made at technical conferences.

The SWRES staff completed a stand-alone PV system manual for Sandia's Design Assistance Center (DAC) in 1988. Five small businesses joined forces with the SWRES to ensure realism in this handbook. The abstract, figure 1, contains the objectives that were set forth for this effort.

Dr. V. Risser visited the Gansu Natural Energy Research Institute (GNERI) in western China in April/May 1988 as a visiting lecturer under a United Nations program. This interchange is the result of an ongoing exchange of personnel and information about alternative energy ideas and techniques. To further this interchange, a proposal was written for a project to introduce photovoltaic systems into western China. The proposal was accepted and will be co-funded by the United Nations Development Program and the government of China.

The SWRES engineers wrote a handbook titled "Data Acquisition Systems-Planning and Installation" for anyone considering the design, specification, and installation of a small computer based remote data acquisition system as part of an EPRI contract. After reading this manual, an engineer unfamiliar with DAS's should be able to select and install sensors, dataloggers, communication equipment, 


\section{Stand-alone Photovoltaic Systems}

A HaNDBOOK OF

Recommended Design Practices

\section{PHOTOVOLTAIC DESIGN ASSISTANCE CENTER \\ SANDIA NATIONAL LABORATORIES \\ ALBUQUERQUE, NEW MEXICO}

NEW MEXICO SOLAR ENERGY INSTITUTE LAS CR.UCES, NEW MEXICO

\section{APPROPRLATE TECHNOLOGY ASSOCIATES}

Carbondale, Colorado

SOLAR WORKS OF VERMONT

Montpelier, Vermont

REMOTE POWER INC.

Ft. Collins, Colorado

SOLAR ENGINEERING SERVICE

Olympia, Washington

OLIVE CORROSION CONTROL

Shreveport, Louisiana

Figure 1. Cover Sheet of the Stand-Alone Handbook. 
computers, and software. The manual is written in an easy to read format with frequent use of photographs and graphics when needed to explain certain aspects of system installation.

In addition to all the projects mentioned above, the SWRES continues to operate and monitor the five grid-connected prototype photovoltaic systems built by DOE as part of the SWRES project. Their characteristics are given in table 2. Data from each system were collected every 5 seconds and averaged to produce hourly data files. The five systems had operated for the last six years without significant failures, downtime, or degradation. However, some power production losses occurred in 1988 due to physical problems within the arrays or system. Solarex had four string failures in 1988. Three strings had corroded connectors resulting in an open circuit. A switch failure in the maintenance panel caused power loss in one string.

TABLE 2

SWRES System Characteristics

\begin{tabular}{l|c|c|c|c|c}
\hline \hline & $\begin{array}{c}\text { Area } \\
\left(\mathrm{m}^{2}\right)\end{array}$ & $\begin{array}{c}\text { Installed } \\
\text { Rating }(\mathrm{kW})\end{array}$ & $\begin{array}{c}\text { i987/1988 } \\
\text { Rating }(\mathrm{kW})\end{array}$ & $\begin{array}{c}\text { Tilt } \\
\text { Angle }\left(^{\circ}\right)\end{array}$ & $\begin{array}{c}1988 \\
\text { PCS }\end{array}$ \\
\hline & 55.2 & 4.9 & $2.5 / 2.5^{*}$ & 45 & Onnion \\
ARTU & 70.2 & 5.1 & $4.6 / 3.9$ & 26 & Teslaco \\
Solarex & 5.3 & $5.0 / 4.9$ & 30 & Omnion \\
TriSolarCorp & 58.0 & 5.5 & $2.8 / 2.8^{*}$ & 30 & Fraunhofer \\
Westinghouse & 72.9 & 3.9 & $4.0 / 3.7$ & 30 & APCC \\
MSEC & 53.0 & 3.9 &
\end{tabular}

* Configuration Changed from Original

The MSEC array has a problem with one module in String No. 1. The MSEC Ra-180 module has six internal by-pass diodes, one for each group of twelve cells in series and three in parallel. One group of cells is by-passed. Also, there may be some degradation occurring in this array. We will continue to monitor performance and MSEC engineers are wcrking with us to fix any problems. The TriSolar, ARTU, and 
Westinghouse systems operated without failure in 1988. This latter system used the Fraunhofer PCS from Germany. This marked the second full year of operation of this unit without a failure. The testing of this PCS will terminate in early 1989.

\subsection{TASK 1: SWRES GRID-CONNECTED SYSTEMS PERFORMANCE}

The solar insolation received in 1988 was 17.4 percent lower than the typical meteorological year (TMY) for El Paso, figure 2, and 11.5 percent less than 1987. The fall and winter months were particularly low. The SWRES has not received the TMY estimated insolation in any of the past seven years, but this is the lowest level since the SWRES started recording data.

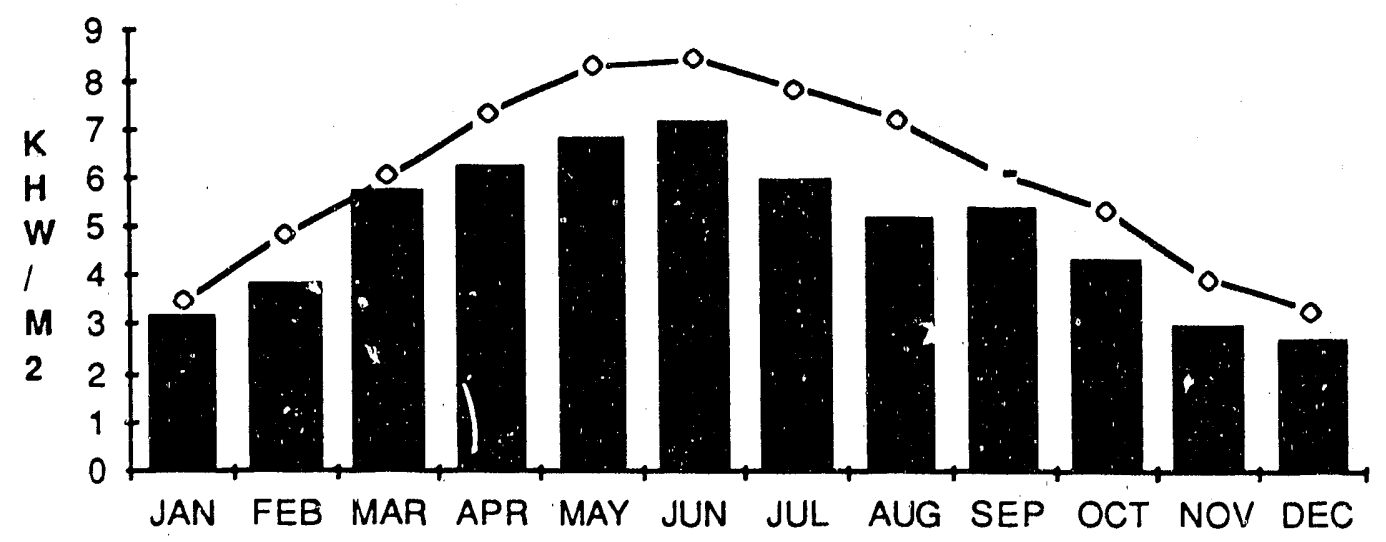

Figure 2. 1988 Horizontal Insolation Comparison with El Paso TMY.

Figure 3 shows the drop in insolation received and the associated drop in production on the systems. As explained in Section 2.1, the drop in TriSolar was compounded by shutdowns for scheduled testing. Failures occurred on the Solarex and Mobil Solar Energy Corporation (MSEC) systems. 


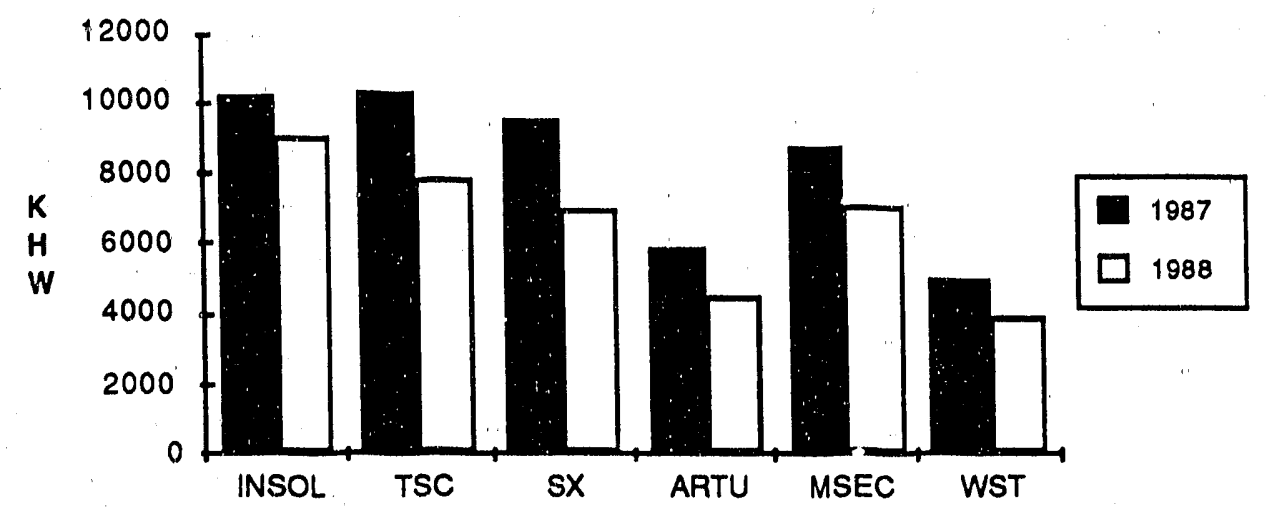

INSOL is five times the total annual horizontal insolation recelved at the SWRES (in $\mathrm{kWh} / \mathrm{m} 2$ )

Figure 3. DC Energy Production Comparison for 1987 and 1988.

\subsection{TriSolarCorp System}

This system produced $7,816 \mathrm{kWh}$ of energy in 1988 . This is consistent with the average annual production in 1982-1987, figure 4 . There were 45 days of downtime scheduled for various tests. The TriSolar prototype is the most reliable system and the one used most often for special tests. If this downtime is factored in, TriSolar would have produced about $8,713 \mathrm{kWh}$. The system rating determined from $\mathrm{i}-\mathrm{v}$ curves taken in 1988 gives a value of $4.9 \mathrm{~kW}$ at standard test conditions $(1,000$ $\mathrm{W} / \mathrm{m}^{2}, 25^{\circ} \mathrm{C}$ module temperature).

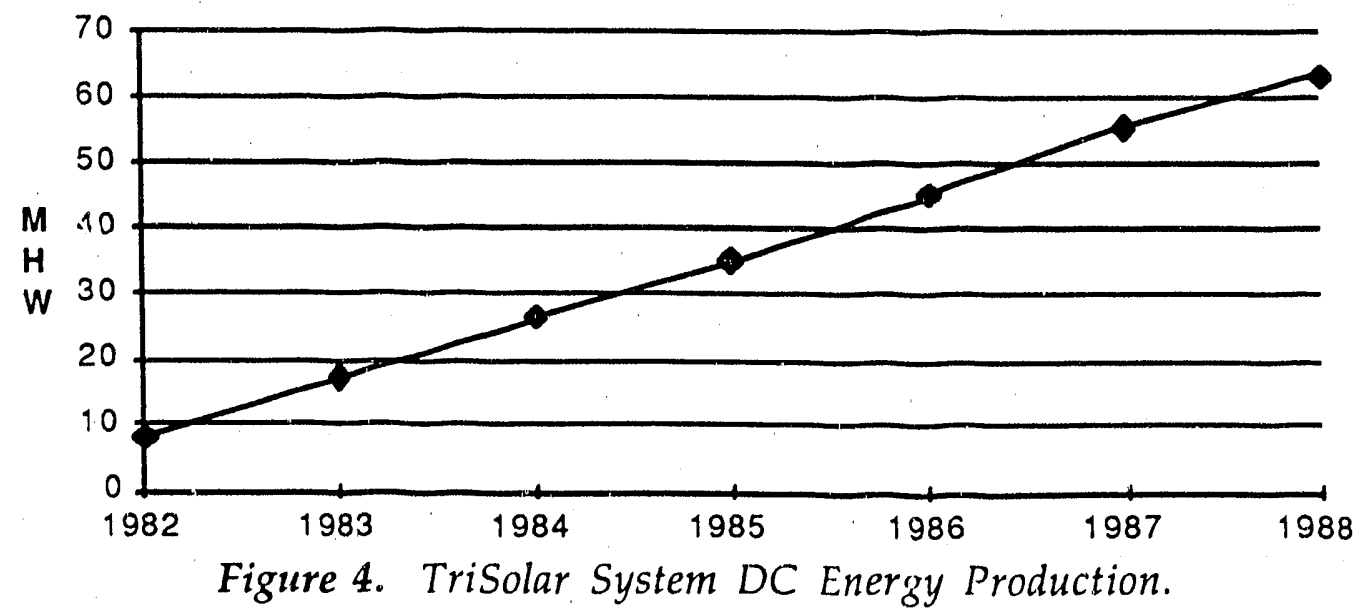




\subsection{Solarex System}

This system produced $6,970 \mathrm{~kW} / \mathrm{l}$ of energy in 1988. The cumulative energy production for this system is given in figure 5 . There were 42 days of downtime for repairs. The I-V curves, taken in 1988 vary because of the problems experienced. The rating at standard test conditions (STC) is $3.9 \mathrm{~kW}$ at the end of the year. This is about 15 percent lower than the ratings given in 1986 and 1987 even though all repairs have been made. We have not found a problem that explains this discrepancy. We continue to monitor performance and in early 1989 the system is producing consistently, but at a lower level.

The Solarex system required maintenance several times in 1988 to correct loss of power in parts of the generating system. Three problems occurred in the array, the most frequent failure being the string connections. The connections corroded until the string was disconnected from the bus and not contributing any power. Also, one of the switches in the dc maintenance panel failed and was removed. The string was hardwired to the bus and the switch was removed.

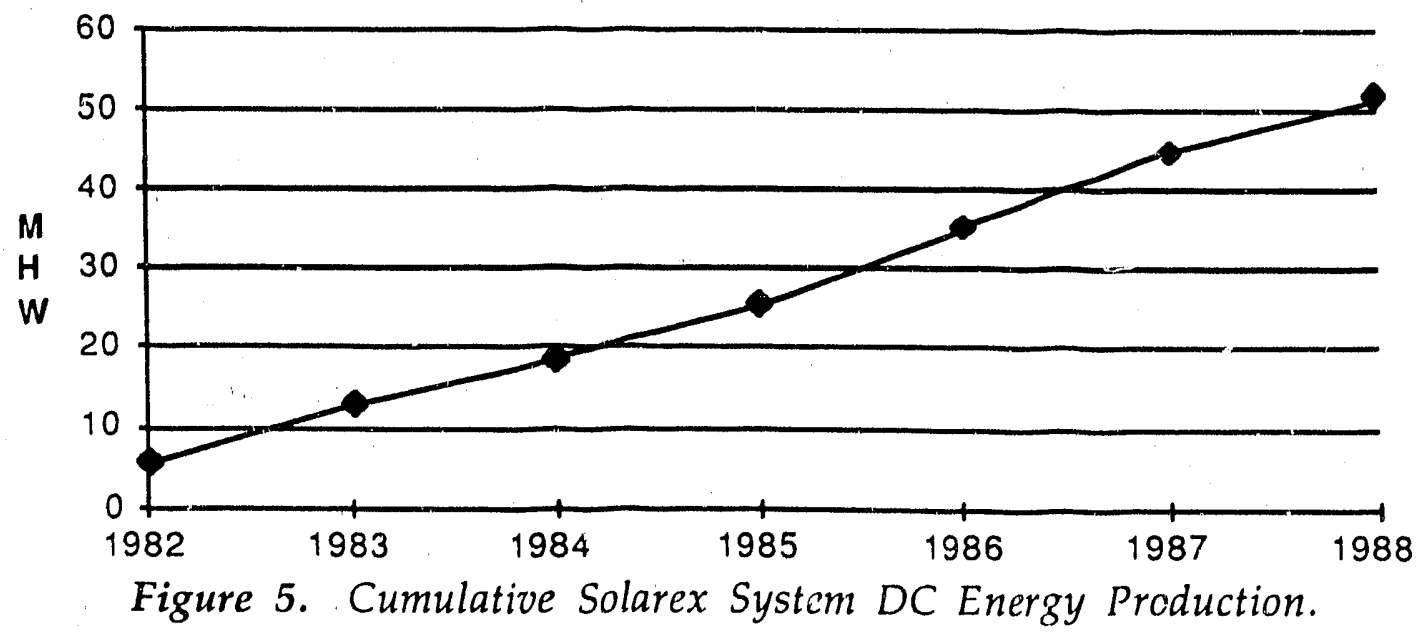




\subsection{ARTU System}

The ARTU system proauced $4,477 \mathrm{kWh}$ of power in 1988 . The energy production trends are shown in figure 6 . The system rating at standard test conditions is $2.5 \mathrm{~kW}$ based on I-V curves taken in 1988. This is the same rating that was given in 1987 In 1985, one third of this array was removed to support other testing. This caused the noticeable decrease in the annual production trend.

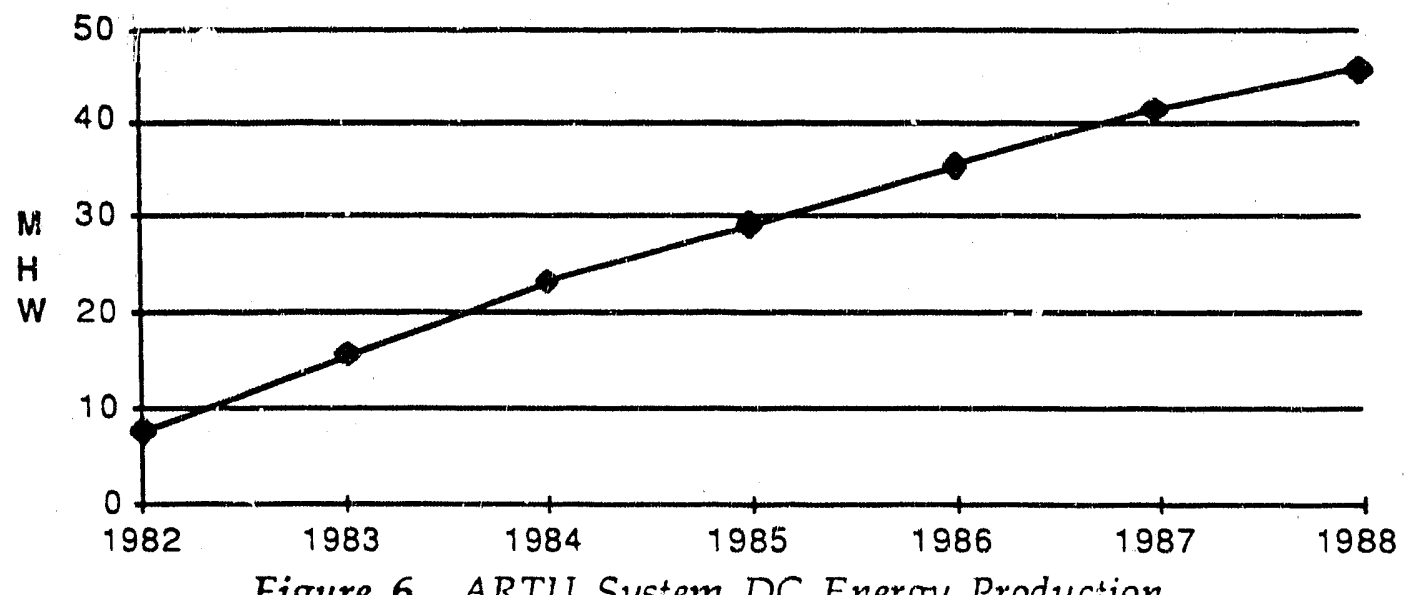

Figure 6. ARTU System DC Energy Produciion.

\subsection{Westinghouse System}

The Westinghouse system produced $3,926 \mathrm{kWh}$ of energy in 1988. There were 10 days of scheduled downtime. The energy production is shown in figure 7. The system rating of $2.8 \mathrm{~kW}$ for 1988 was determined from I-V curves.

\subsection{Mobil Solar System}

This system produced $7,021 \mathrm{kWh}$ of energy in 1988. The energy production is given in figure 8. Two failures occurred; a fuse in the ac side of the inverter opened for an unknown reason, and one by-pass diode in String No. 1 is conducting. The latest I-V curves taken in 1988 showed a drop in system rating to $3.7 \mathrm{~kW}$. This is 

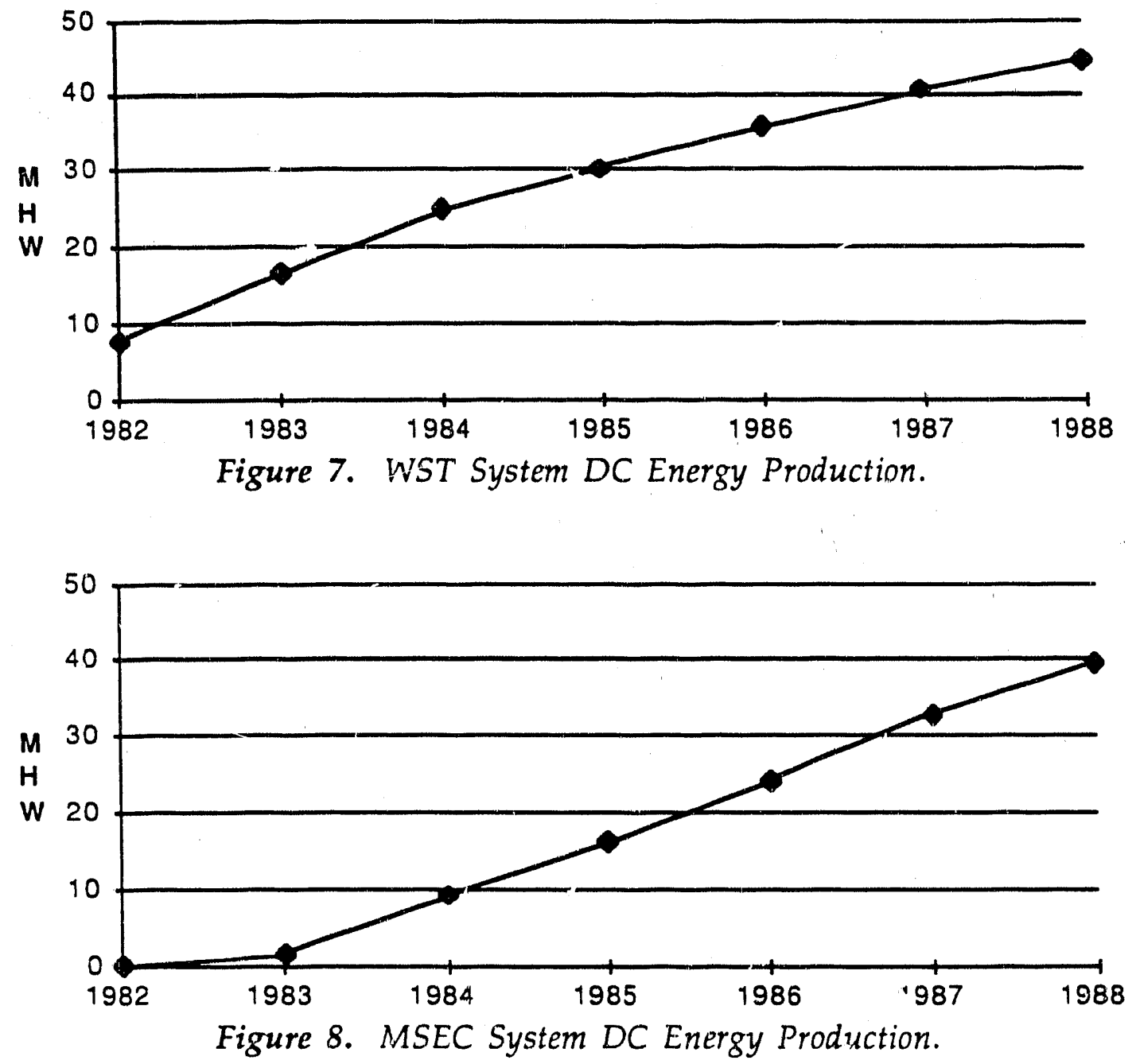

caused in part by the v'eak module in String No. 1. However, some other factors may be causing a decrease in power. We have contacted MSEC engineers and we will continue to monitor system power.

\subsection{TASK 2: ON-SITE EVALUATION OF PV SYSTEMS}

Eleven systems were tested in 1988. Reports on system status and test results are prepared after each system evaluation. A summary of test results are given for those systems tested under the DOE rontract. 


\subsection{Newman Power Station System}

The Newman Power Station Photovoltaic system was tested March 14, 1988. This system has been operating since January 1981 and provides power to the El Paso Electric Company's (EPEC) Newman Power Station. Five hunrired seventy-six Solar Power Corporation's G12-361-CT modules are installed in 64 wooden frames and face due south at a fixed tilt angle of $26^{\circ}$. The dc output of the array is tied to the uninterruptible power supply (UPS) used for Newman Power Station control.

During the testing, the system was operating and providing about $12 \mathrm{~kW}$ to the UPS. A visual inspection of the array showed no shattered modules or other apparent problems. Electrical testing of each of the six subarrays showed a blown fuse had interrupted power flow from the North-East Subarray, figure 9, and 11 strings of 9 modules each were noncontributing. I-V curves of all six strings were taken as well as an I-V curve of the array (without contribution of the North-East Subarray). These curves were normalized and the results used to determine the array power rating.

The system was rated at $15.8 \mathrm{~kW}$ under standard test conditions of $1,000 \mathrm{~W} / \mathrm{m}^{2}$, and $28^{\circ} \mathrm{C}$ module temperature. This rating was determined by adding the peak power of all six subarray I-V curves, and checked by adding the power of the northeast subarray to the array I-V curve to compensate for the noncontributing subarray. This rating is about 6 percent less than the rating $(16.9 \mathrm{~kW})$ assigned during the last systern test in October 1985.

No module problems were found. Full array output was restored after replacing the fuses in the subarray switch box. 


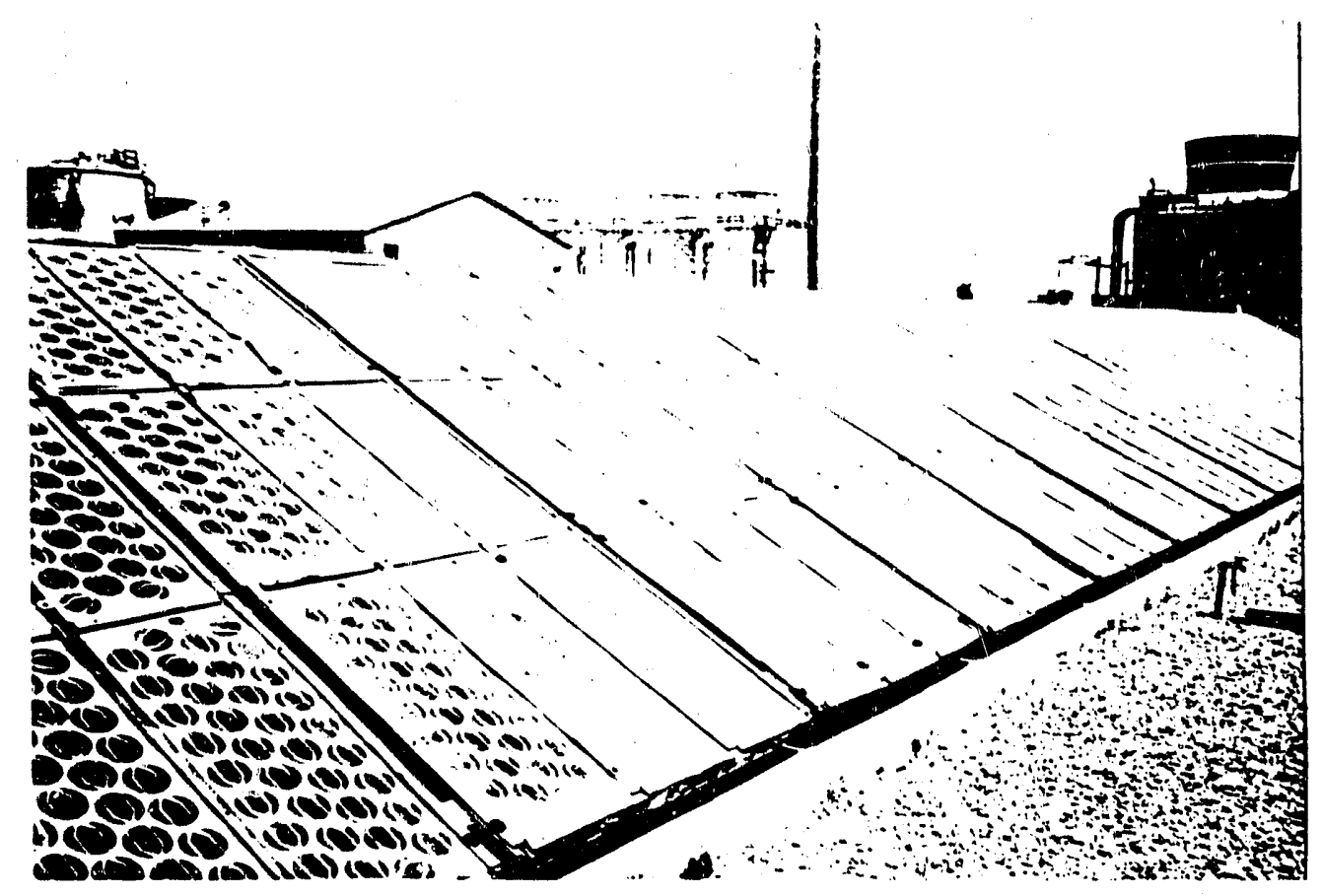

Figure 9. Newman Power Station System.

\subsection{Philadelphia Electric Company (PEC)}

The PEC PV systems, figure 10, were tested July 14. The PEC testbed is used to measure the performance of the Solarex amorphous silicon (a-Si) modules. There are several different generations of modules represented. There are two operating systems at the site. Their ratings were calculated as $775 \mathrm{~W}$ and $3.85 \mathrm{~kW}$ at standard operating conditions of $1,000 \mathrm{~W} / \mathrm{m}^{2}$ irradiance and $46^{\circ} \mathrm{C}$ module temperature.

Several module failures were noted, but because this is a test bed with many prototype modules, these data were not significant. 


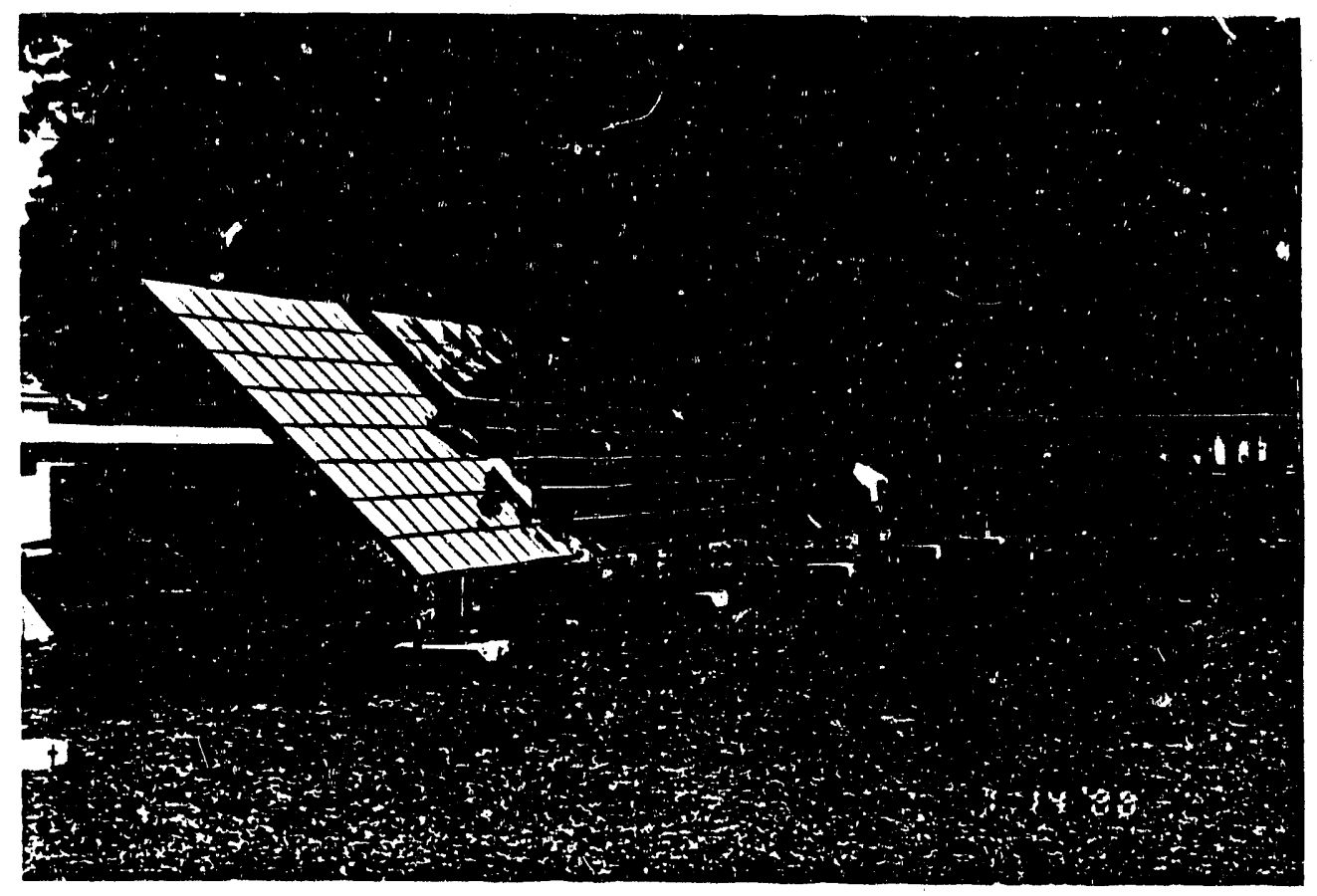

Figure 10. Philadelphia Electric Test Facility near Limerick, Pennsylvania.

\subsection{Georgetown University System}

Two tests of the Georgetown University PV system, figure 11, were performed in 1988. The array was first tested July 13, 1988. Data were evaluated and a system rating of $210.2 \mathrm{~kW}$ was calculated at standard test conditions of $1,000 \mathrm{~W} / \mathrm{m}^{2}$ irradiance and $25^{\circ} \mathrm{C}$ module temperature.

At an operating temperature of $46^{\circ} \mathrm{C}$, the rating is $195.0 \mathrm{~kW}$. This is a drop of 22 percent from the rating assigned in April 1985. There are 39 modules that are noncontributing.

On November 3, 1988, more testing was performed at Georgetown to determine the reason for the large drop in rated power of the system. At that time, five spare modules that had never been used were tested and compared to modules that had been installed in 1984. Selected modules in the array were scrubbed and the increase 


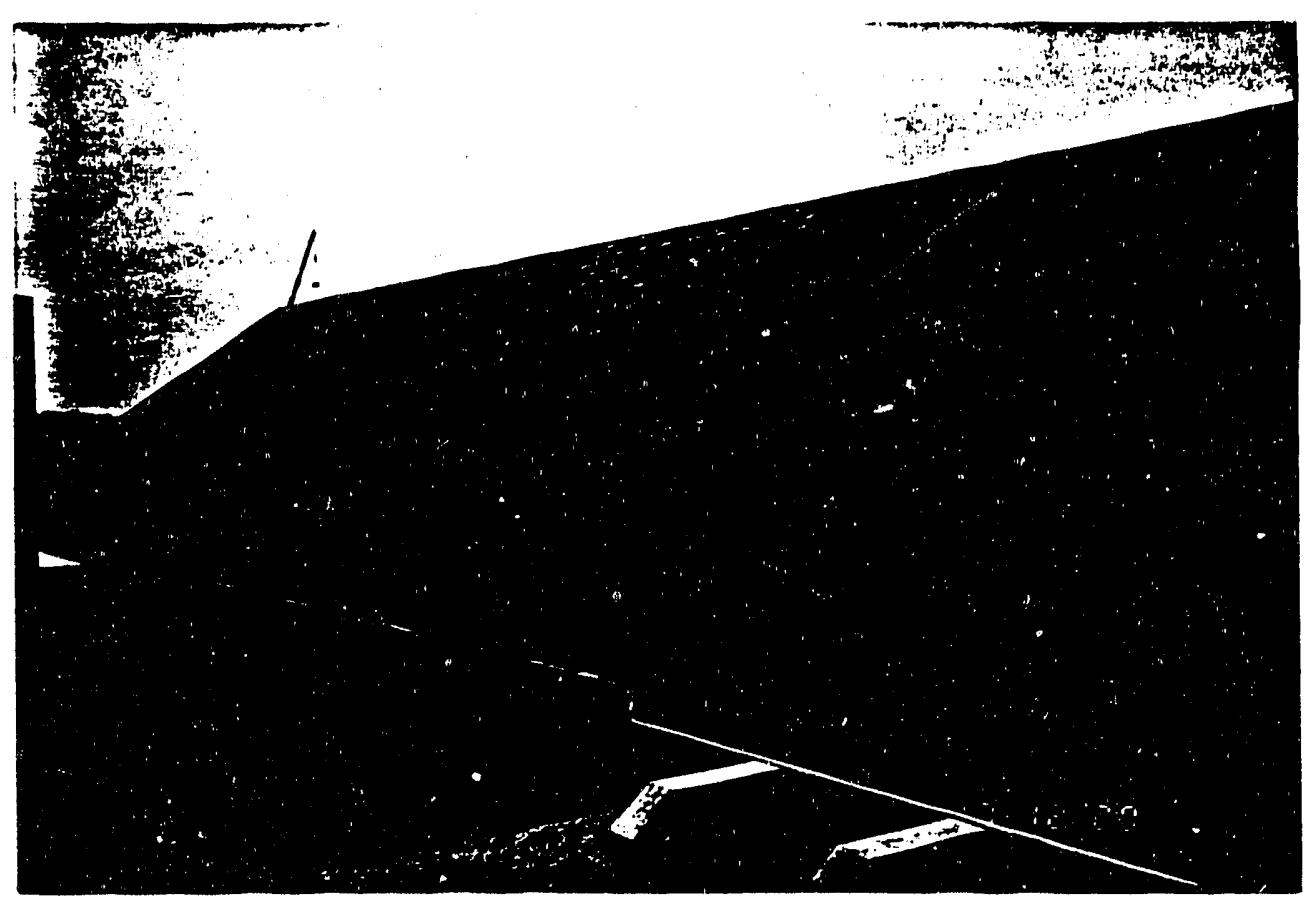

Figure 11. Georgetown University System.

in power output of the clean modules was measured. It was possible to increase the output power of the modules by 23 percent if they were scoured with a nonabrasive pad and a solution of soap and ammonia. However, the cleaned modules did not equal the output from the spare modules (by 9.5 percent). An array rating of $268 \mathrm{~kW}$ would be assigned if the entire array were cleaned, an increase of $58 \mathrm{~kW}$ over the rating determined in July.

\subsection{Puerto Rico}

Testing of the Juana Diaz PV system was conducted March 1-2, 1988. This system, figure 12, has been operating since June 1987 and provides power to the Puerto Rico Electric Power Authority (PREPA) grid. Solarex Corporation installed the system and used SXP-44 polycrystalline modules. The PCS was manufactured by Omnion Incorporated. Three phase ac power output at $12.4 \mathrm{kV}$ is supplied to the PREPA grid. 


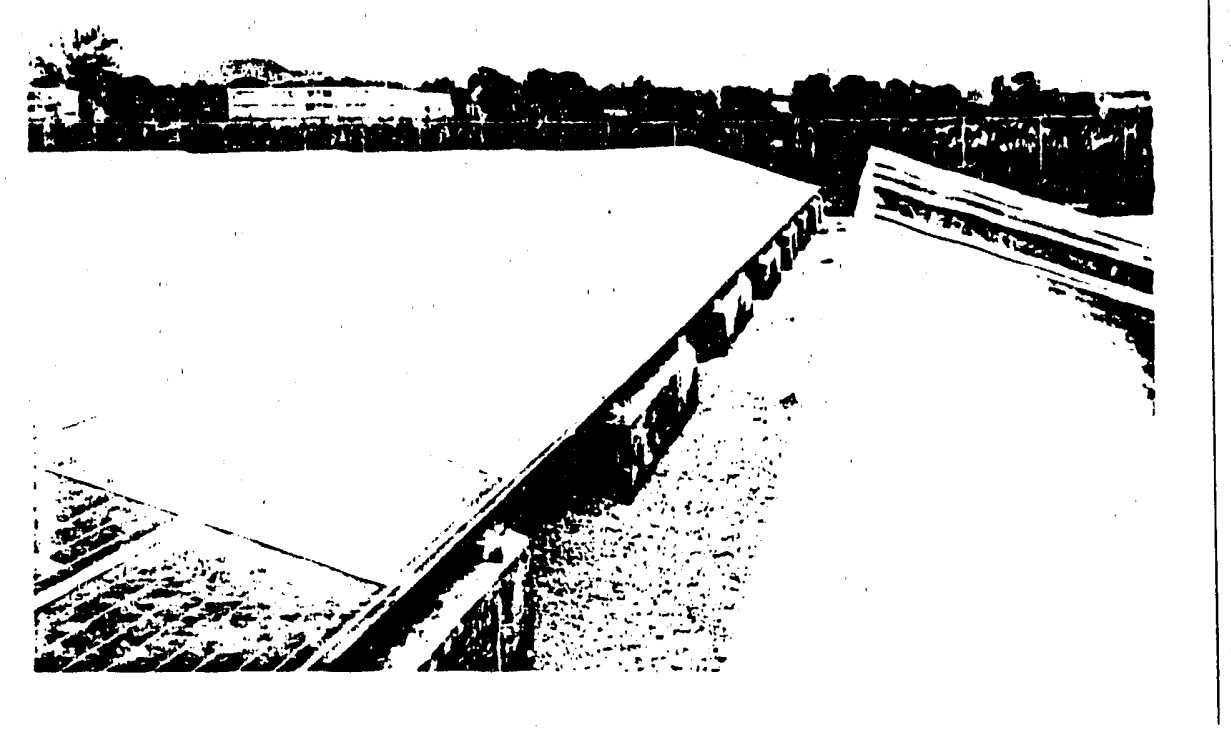

Figure 12. Juana Diaz PV System in Puerto Rico.

Two problems were found in the PV array. One PV module superstrate was shattered. The impact mark from a rock or other object was clearly visible. The power output from the module was not affected, but the lifetime of the module will probably be shortened because of exposure of the cell interconnections to the weather. The other problem was causing loss of power from one module (two laminates). The by-pass diode around this module was conducting and carrying the string current. The positive junction box on one of the laminates showed signs of high temperatures. The cover of the junction' box had melted and could not be opened without breaking the box. This was not done, so the exact cause of the problem was not determined. The two laminate module should be replaced. The system was rated at $90.4 \mathrm{~kW}$ when operating under standard test conditions of $1,000 \mathrm{~W} / \mathrm{m}^{2}$, and $28^{\circ} \mathrm{C}$ module temperature. 


\subsection{TASK 3: REMOTE FIELD SITE DATA ACQUISITION}

Hourly performance data from eight photovoltaic systems was collected at the SWRES during 1988. The eight systems include five crystalline and three amorphous silicon arrays.

1. Hesperia

2. Detroit

3. Alabama

4. Virginia

5. Dallas

6. San Diego

7. Georgetown

8. Florida Power Corp.
Two-axis tracking flat plate ARCO modules Fixed a-Si Sovonics modules Fixed a-Si Chronar modules Three separate testbeds, Solarex and ARCO modules Linear Fresnel Concentrator--Entech modules Residential systems, flat plate ARCO modules Fixed flat plate, roof mounted, Solarex modules Fixed a-Si ARCO modules

These data are checked for quality, formatted and archived at the SWRES. Selected data are provided to SNL and EPRI. Two of the eight sites, Dallas-Fort Worth Airport and San Diego Gas and Electric's Laguna del Mar have discontinued data collection. These two data acquisition systems were turned off in 1988.

\subsection{TASK 4: SYSTEM ANALYSIS}

\subsection{Effects of Failures and Maintenance on PV System Performance}

The SWRES staff worked on a co-funded project for DOE and EPRI to develop a simulation program and study the effects of failures on PV system performance. A report describing the simulation program and presenting results obtained from studying a SMUD type sample system was prepared. Also, a paper was delivered at the IEEE Convention in Las Vegas in September 1988. The following summary is excerpted from the report. 
Based on TDI field test experience, estimates were made for diagnostics and maintenance cost and these were compared to the value of energy saved by maintenan se. The benefit from maintenance versus maintenance interval is shown in figure 13 for three different failure rates and an exponential failure rate profile.

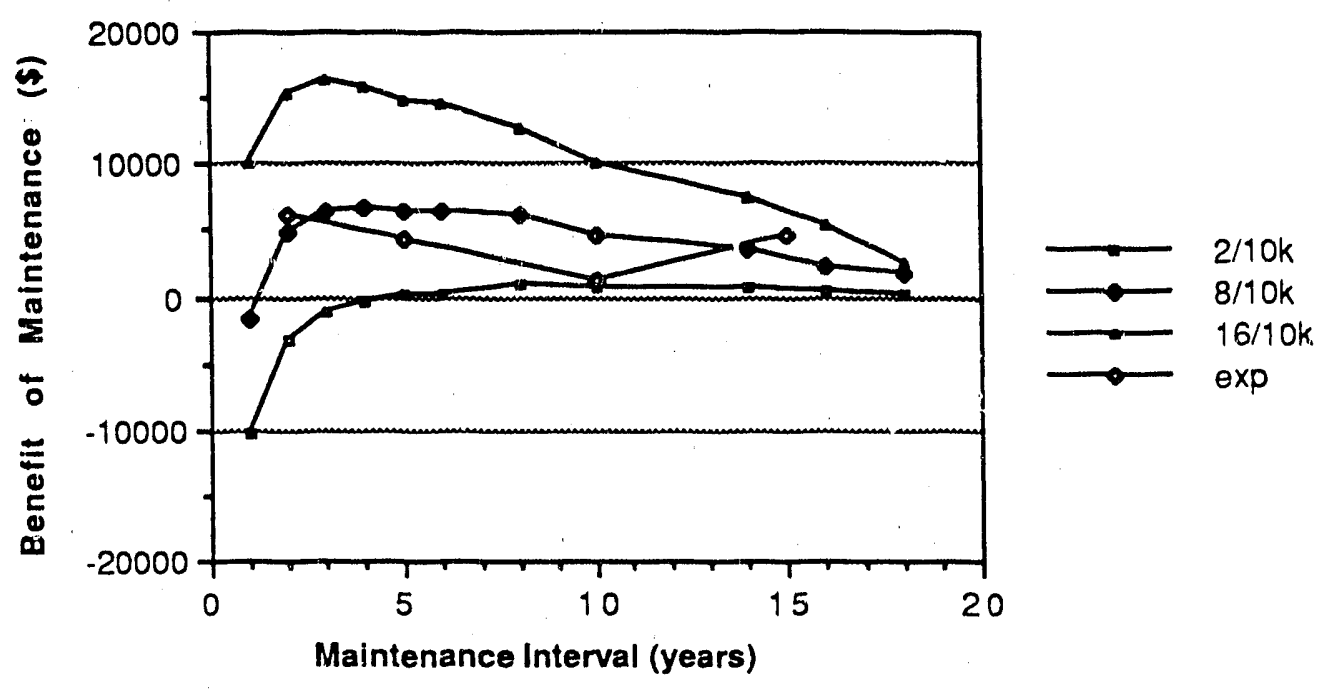

Figure 13. Value of Maintenance vs. Maintenance Interval.

This summary of results shows that:

- Maintenance increased revenues for all constant failure rates if the assumption was made that module replacement was not required.

- The benefits from maintenance decreased as failure rates decreased. For the lowest case studied, 2/10,000 per year, the benefit of maintenance is marginal.

- For higher constant failure rates, there was a significant "knee" in the curve. This indicates that an optimum maintenance program can be defined. 
- For the exponential failure rate, frequent maintenance showed some positive benefit even though in the early years few failures occurred. In the later years a large number of failures occurred and the end of useful system life approached rapidly. However, some maintenance in the later years was beneficial because the end of life could be postponed a few years.

\subsection{Structured Testing at the SWRES}

\subsubsection{Chronar II}

The Chrorar II system was installed on November 23, 1987. The system consists of seventy-two 10 Watt CIM1-3B glass-on-glass modules configured into six 170 volts parallel strings. The system has had no module failures and has no unscheduled down time since installation. The initial efficiency was about 4.5 percent and after 503 days has degraded to about 3.2 percent. Figure 14 shows the normalized output of the array at the end of 1988.

\subsubsection{Sovonics $\mathrm{R}-100$}

The Sovonics R-100 system was installed on March 28, 1987. The system consists of thirty-six 32 Watt R-100 modules configured in twelve parallel 42 volt strings. The system had one failed module which was detected during initial checkout but has had no other failures. The initial system efficiency was about 3.6 percent and has degraded to 3.3 percent after $6 \varepsilon 0$ days. Figure 15 shows an I-V curve for the array taken on December 16, 1988.

\subsubsection{Solarex SA-20 System}

The Solarex SA-20 system was installed on January 7, 1988. The system consists of $48 \mathrm{SA}-20$ modules configured into four 190 volt parallel strings. The modules are mounted on a Unistrut frame which can be tilted up to expose the back of each module. Four modules failed in 1988. The initial system efficiency was 


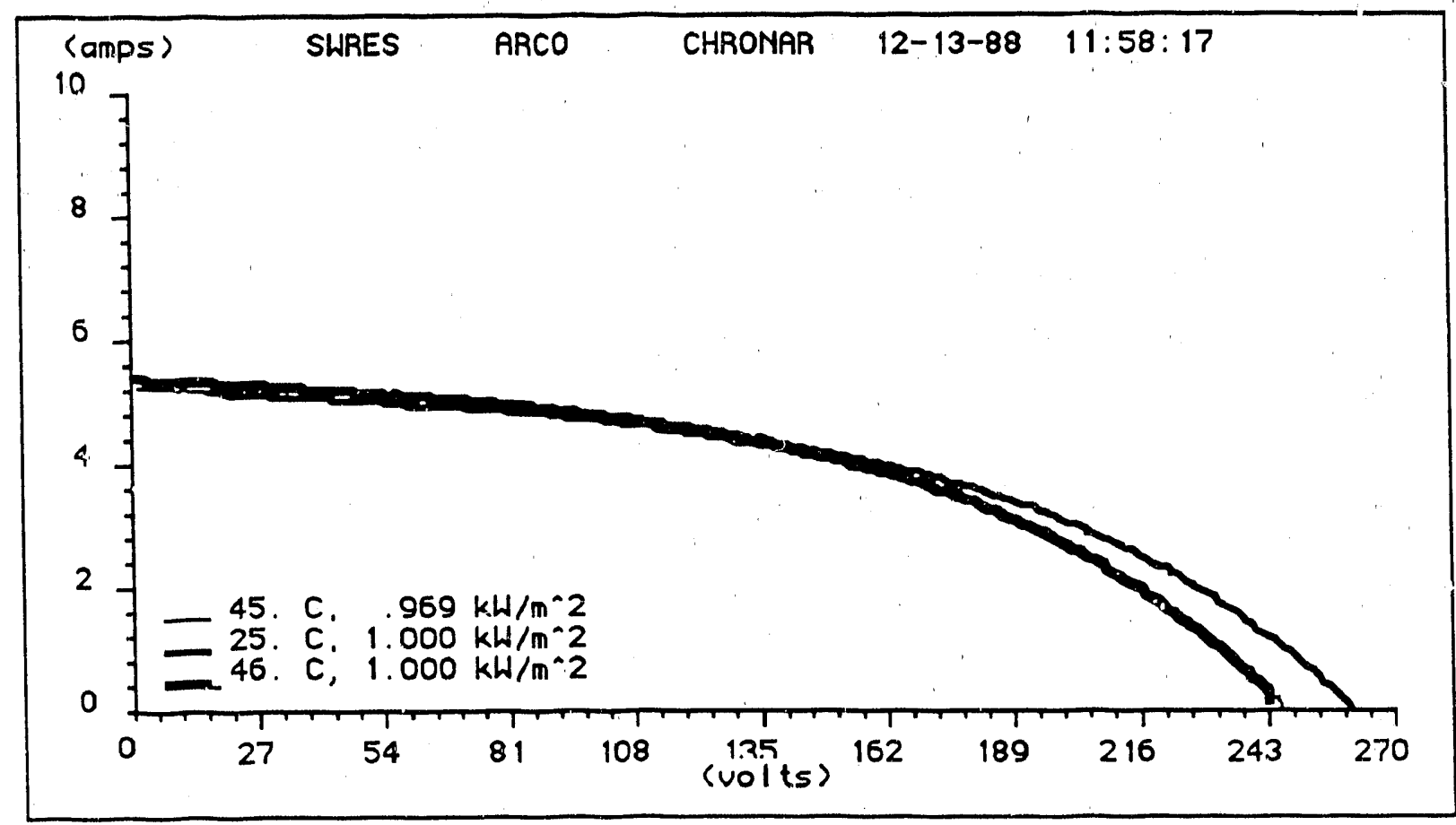

Cell Temperature ........

Irradiance .............

45.000 deg $\mathrm{C}$

Voltage Coefficient ...... - .700 volts/deg C

Current Coefficient ...... .012 amps/deg C

ACTUAL CURUE DATA: ( $i$ ill factor $=47.68$ )

Short circuit current .... 5.3 amps

Open circuit voltage ..... 245.5 volts

Max power current ....... 3.7 amps

Max power voltage ........ 165.2 volts

Max power ...........6 614.7 watts

NORMALIZED CURUE DATA: ( $\mathrm{i} i \mid$ ) factor $=48.88$ )

(for 25.0 deg $C$ and $1.0 \mathrm{~kW} / \mathrm{m}^{-2}$ )

Max power current ....... 3.8 amps

Max power voltage ........ 173.2 volts

Max power .............658.1 watts

NORMAL IZED CURUE DATA: ( $\mathrm{f} i \mid l$ factor $=48.08$ )

(for 46.0 deg $C$ and $1.0 \mathrm{~kW} / \mathrm{m}^{\wedge} 2$ )

Max power current ....... 3.9 amps

Max power vol tage ........ 162.4 volts

Max power ............ 633.3 watts

Figure 14. Chronar II Normalized Power. 

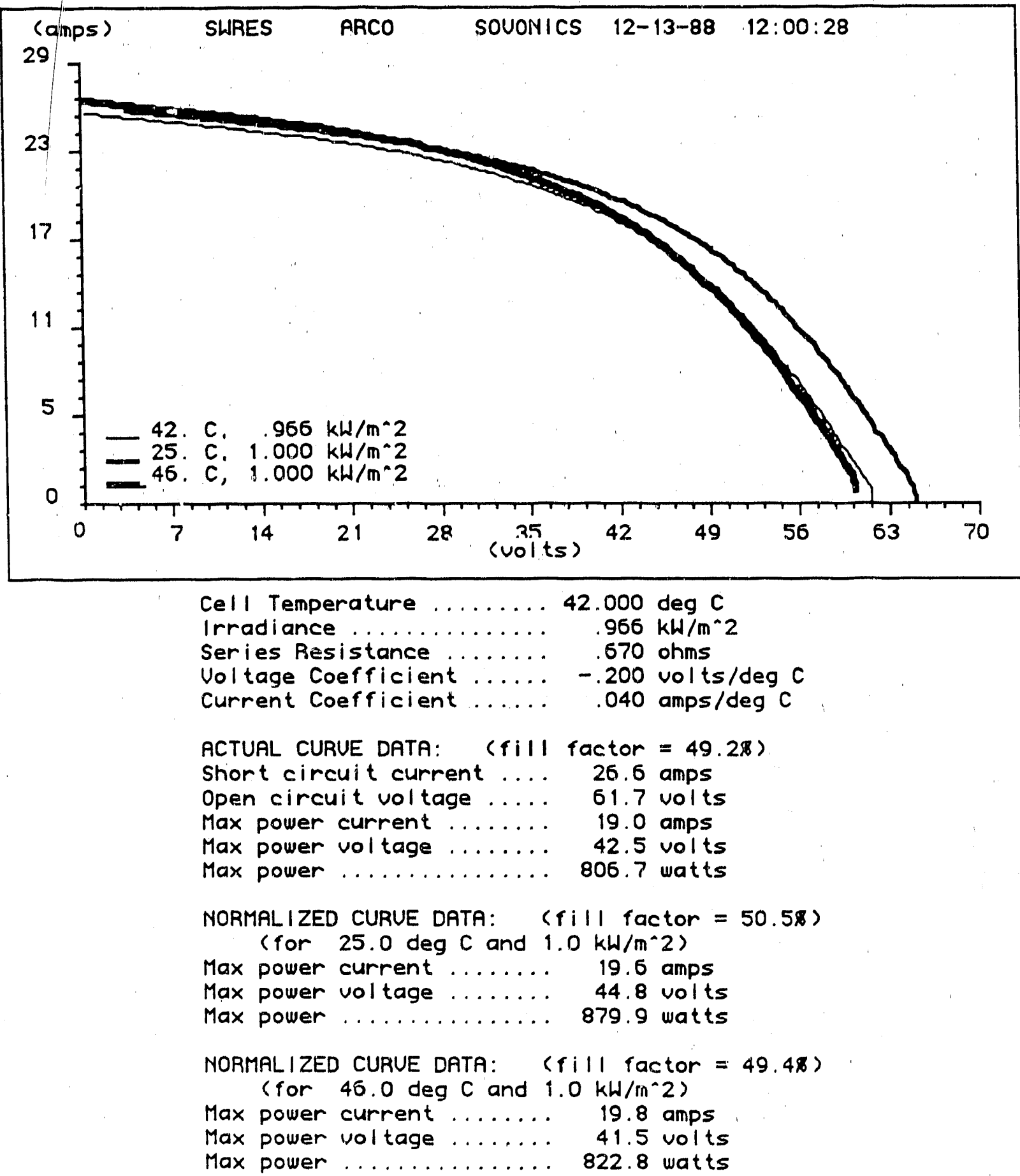

Figure 15. Sovonics R-100 Normalized Power vs. Time. 
about 4.2 percent and has degraded to about 2.6 percent in 350 days. This includes the effect of the four module failures. Without the failed modules the efficiency would be about 3.3 percent. The I-V curves for this system are given in figure 16 .
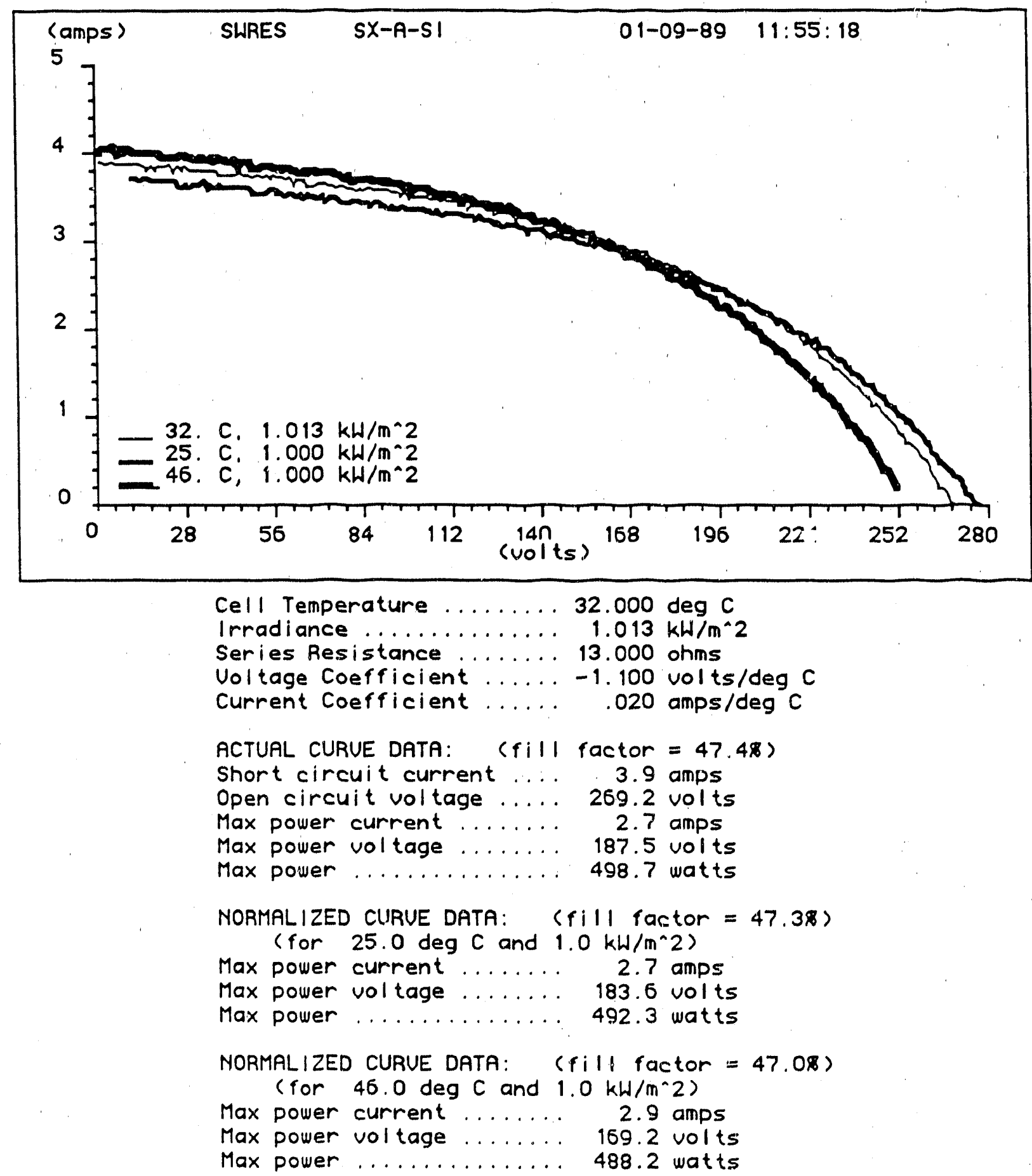

Figure 16. Solarex Normalized Power vs. Time. 


\subsubsection{Sovonics Power Plus}

The Sovonics P-101 power plus system was install on April 19, 1988. The system consists of 40 P-101 modules all connected in series to form a 48 volt array. Seven modules were found shorted to the module frame during initial system test. The shorted modules were returned to Sovonics. Module mismatch is a problem with any array but is worse with this high current, low voltage system. The short circuit current of the 40 modules varies from 9 amps to 15 amps. Since the array is 1 series string, it was impossible to separate and match the modules. The operating voltage of the modules has been measured, and none of the modules are operating in the reversed biased mode. However, there is a wide variation in operating voltages and this mismatch lowers the output from the array. An I-V curve is given in figure 17.

\subsubsection{Sovonics Power Plus II}

Seven Sovonics P102 modules like the ones installed at the PVUSA site were installed at the SWRES in August 1988. This 12 volt system was used to charge a battery in the stand-alone testbed. These modules were replaced in February 1989 with a new version that had passed the "wet hi-pot" test required by PVUSA. An $\mathrm{I}-\mathrm{V}$ curve of the modules installed in 1989 is given in figure 18. 


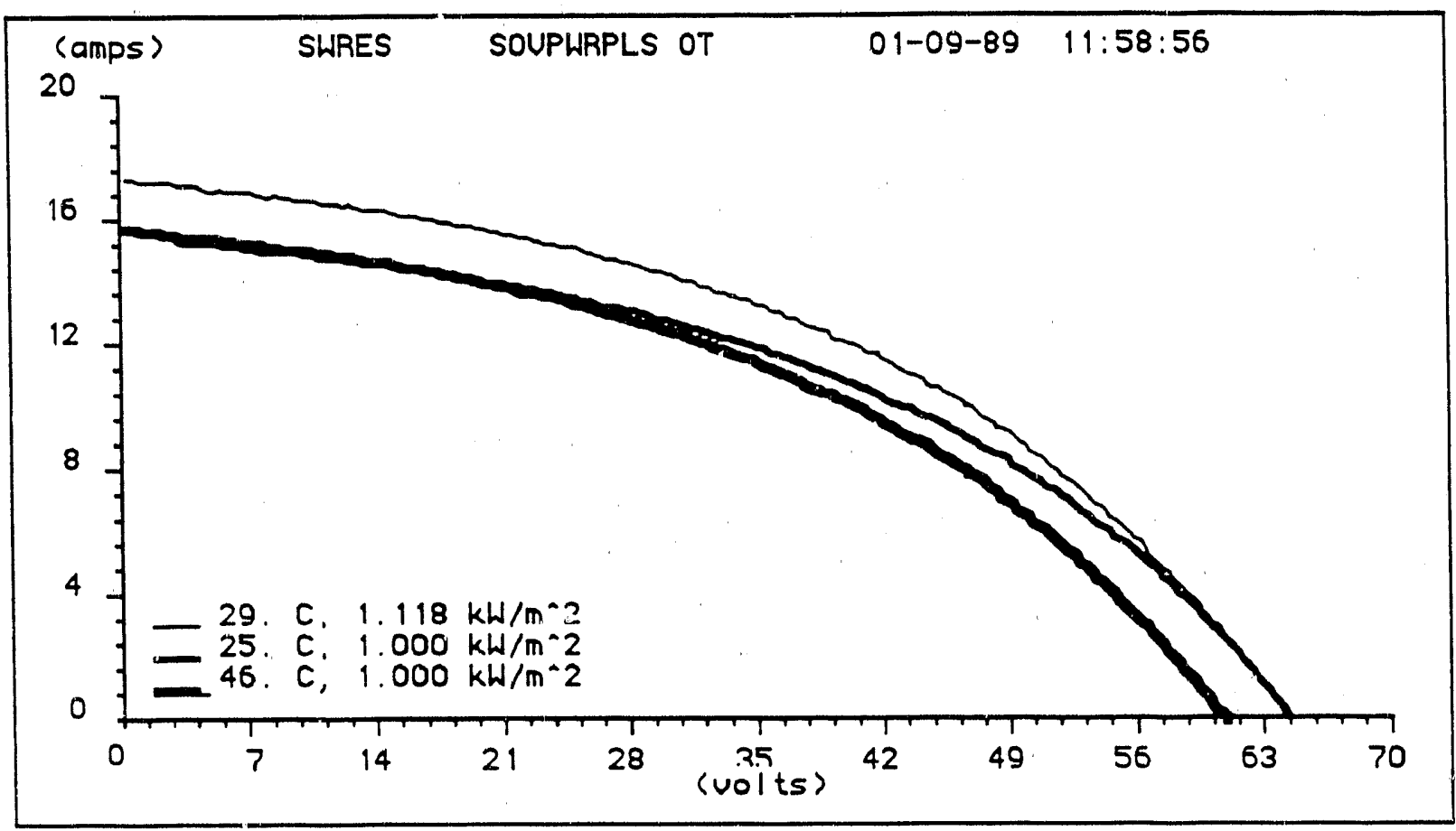

Cell Temperature .......29.000 deg C

Irradiance ........... 1.118 kW/m^2

Series Resistance ....... 1.050 ohms

Voltage Coefficient ...... - . 190 volts/deg C

Current Coefficient...... .027 amps/deg C

ACTLAL EURUE DATA: ( $\mathrm{i} \mid 1$ factor $=44.08$ )

Short sircuit current .... 17.3 amps

Open circuit voltage ..... 64.0 volts

Max power current ....... 11.7 amps

Max power vol tage ....... 41.7 volts

Max power ...........4 486.8 watts

NORMAL IZED CURUE DRTA: ( $\mathrm{f} i \mid$ f factor $=42.48$ )

(for 25.0 deg $C$ and $1.0 \mathrm{~kW} / \mathrm{m}^{\wedge} 2$ )

Max power current ........ 10.4 amps

Max power voltage ....... 41.7 volts

Max power .......... 435.7 watts

NORMALIZED CURUE DATA: ( $\mathrm{i}||$ factor $=4 ! .48)$

(for 46.0 deg $C$ and $1.0 \mathrm{~kW} / \mathrm{m}^{\wedge} 2$ )

Max power current ........ 10.2 amps

Max power voltage ........ 40.0 volts

Max power ........... 409.6 watts

Figure 17. I-V Curve for Sovonics P101 Array. 

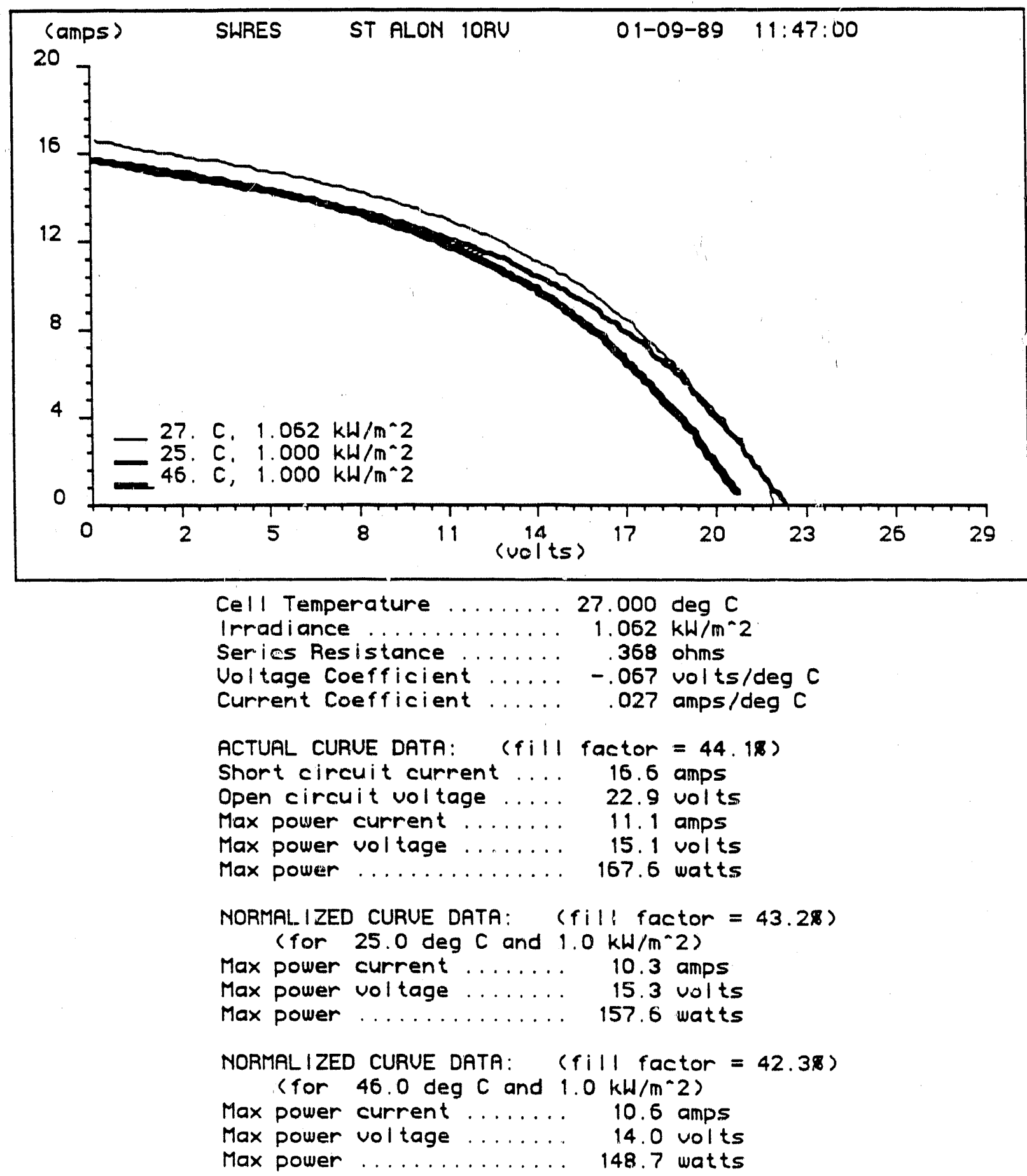

Figure 18. I-V Curve for Sovonics P102 Array. 


\subsection{Lighting of SWRES Sign}

A PV powered light system was installed to illuminate the SWRES sign, figure 19. This is clearly visible from Interstate 10. The light system was donated by a local distributor of PV powered lights. We plan to use the system to check the reliability and performance of selected charge controllers.

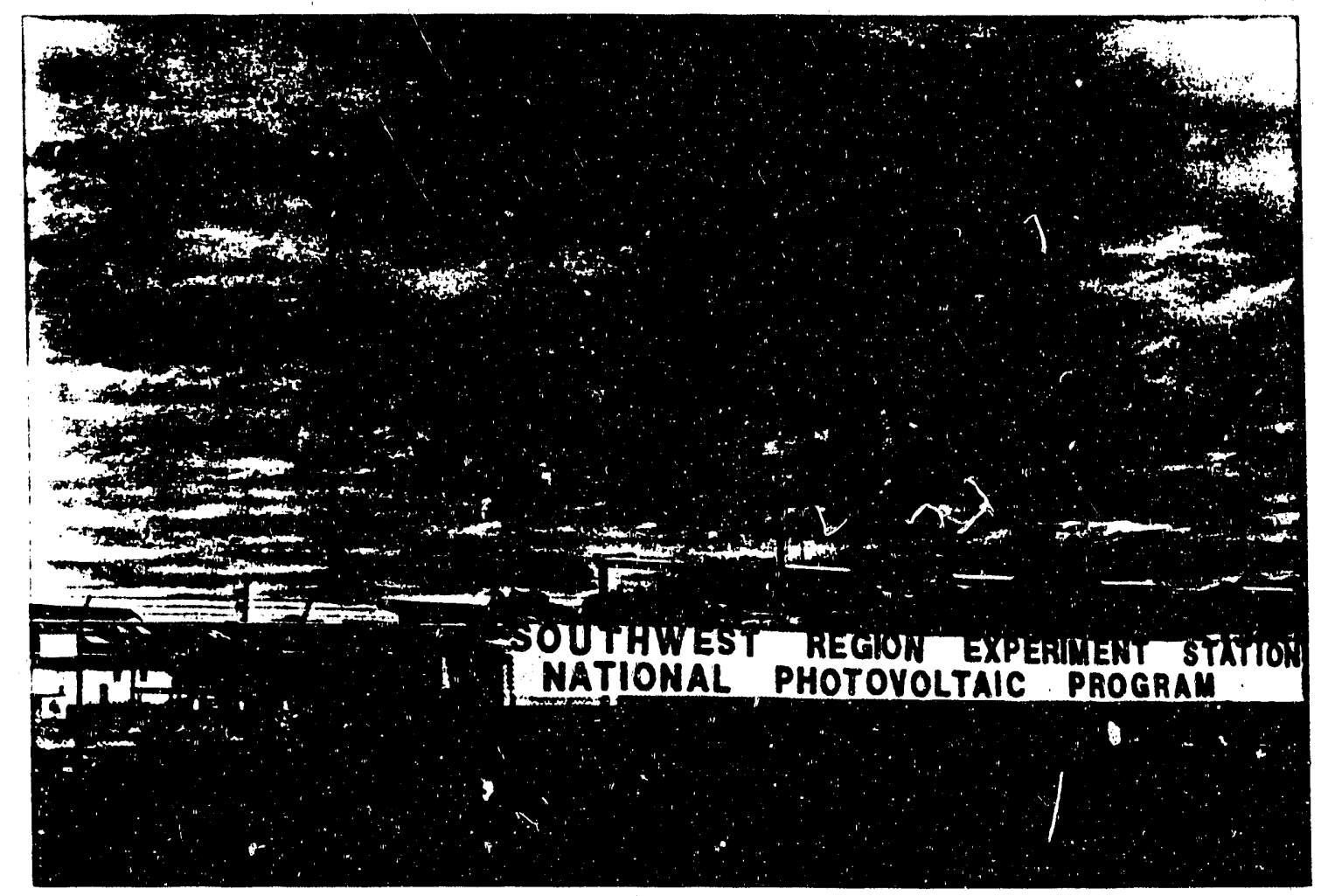

Figure 19. Lighted SWRES Sign.

\subsection{TASK 6: TECHNOLOGY TRANSFER}

Over 256 groups toured the SWRES in 1988. The visitors are given manufacturers brochures, test reports, PV Reading Guides, the 1989 ASE PV Manufacturer Directory, and information about SNL's Design Assistance Center. 
The tours at the SWRES are popular and receive praise from many of the attendees. Secondary school teachers bring their students each school year. The SWRES participared in two outdoor shows in 1988.

\subsection{Centennial Days}

The TDI Solarfest was held on February 26 and 27, figure 20. A booth and display was set up on the campus of the New Mexico State University during the New Mexico State University's Engineering Fair. Over 1,500 people visited the exhibit which displayed passive solar design models, photovoltaic modules, passive heating techniques, and solar ovens. A "Solar for Kids" program entertained and informed over 500 children. Hourly tours of the SWRES were filled to capacity as people toured the stand-alone testbed and the five grid-connected prototypes.

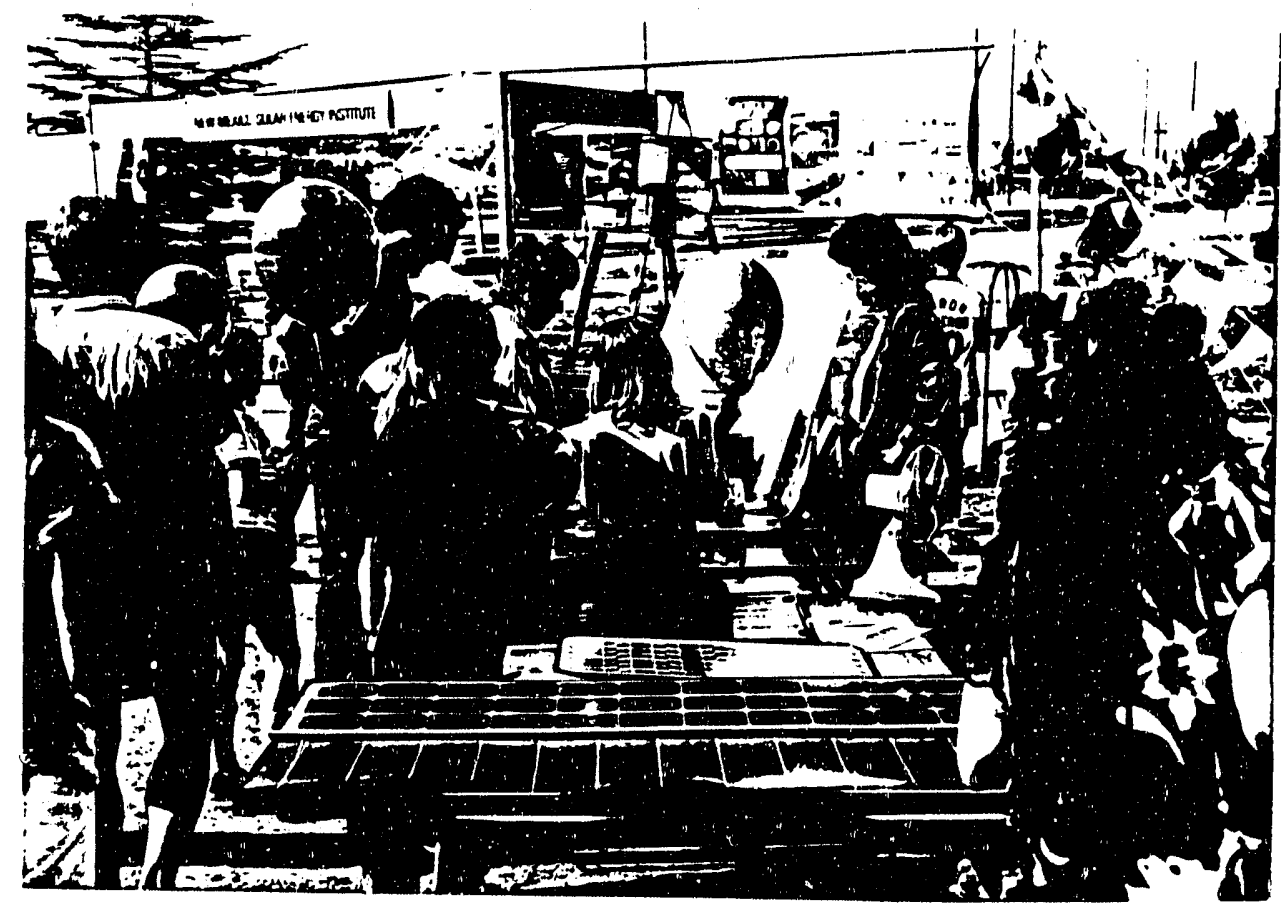

Figure 20. Solarfest. 


\subsection{Antique Farm Equipment Show}

The SWRES participated in the: New Mexico State University Antique Farm Show on October 10. The show was well attended and cver 600 people visited our buoth and obtained information.

\subsection{IEEE Booth}

The SWRES presented a display booth at the IEEE PV Specialists Conference in Las Vegas in October 1988, figure 21. Seven recent publications by SWRES staff were displayed and copies were made available on request. We subsequently mailed over 200 documents to 15 different countries. No DOE funding was used for this activity.

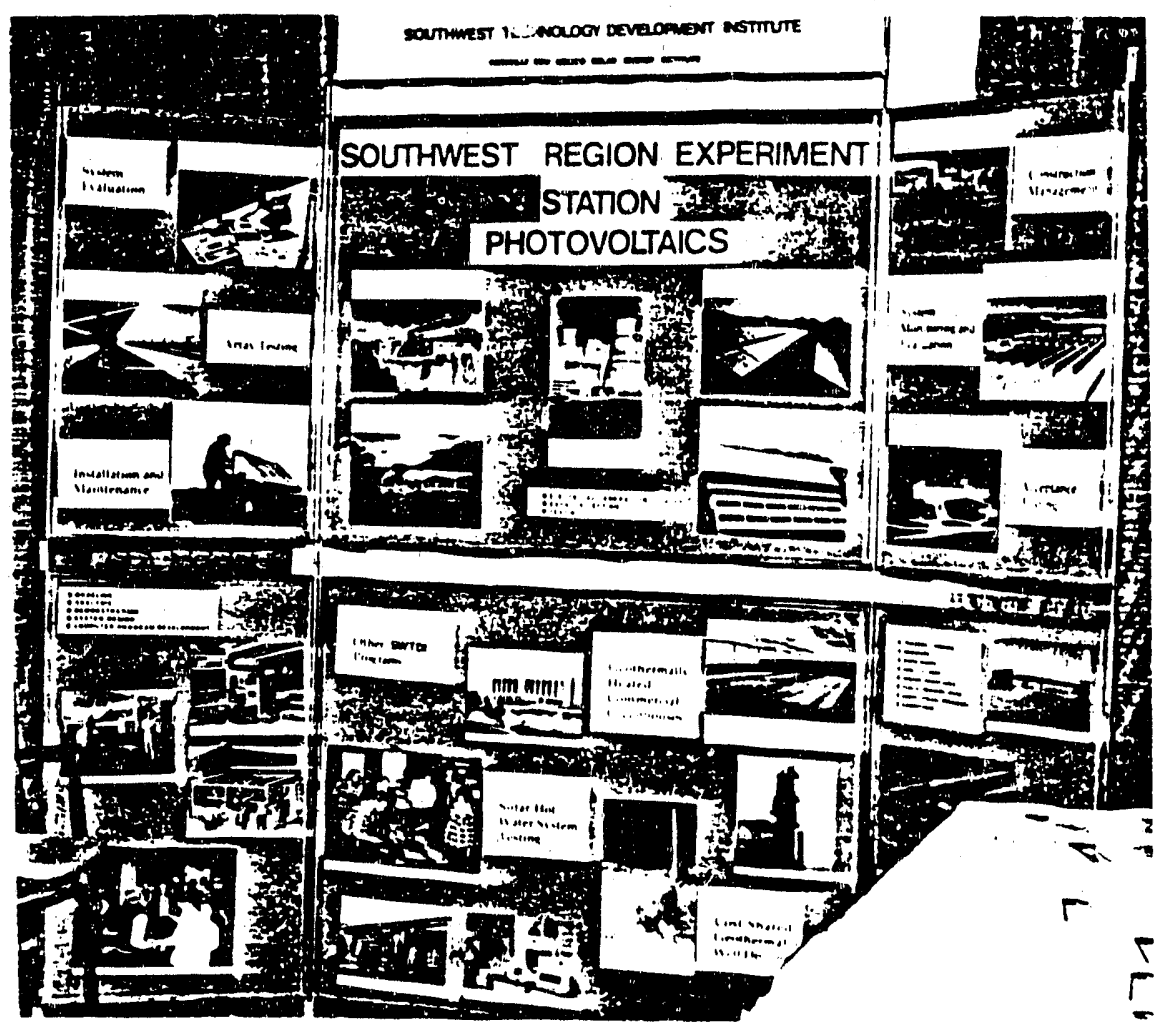

Figure 21. SWRES Booth at PV Specialist Conference. 


\subsection{Papers and Reviews}

SWRES staff presented results of their activities at various meetings. V. Risser and Tim Ball, Solar Electric Specialists, presented a workshop on stand-alone PV system design at the IEEE PV Specialists Conference. The 4 hour session was attended by 75 persons from around the world. The handbook written for the DAC was used as the text for the course. Other papers and publications for 1988 are listed below.

\subsection{DOE Project Review}

A project review was held at the SWRES on March 29, 1988. Personnel from DOE-ALU, SNL, and SERI attended. The system overview presented the results from four 1987 contract tasks performed at the SWRES.

\subsection{OTHER SWRES PROJECTS}

The SWRES staff performs on contracts with a variety of agencies. Some of these projects are summarized in the following sections.

\subsection{G.R.A.D. Balloon Project}

The SWRES designed and built a PV power supply for a balloon borne astronomy experiment. The goal of the experiment was to collect gamma radiation from the Supernova 1987A that was first observed on February 23, 1987. The project was called the G.R.A.D. experiment and was a group project between The University of Florida, the Goddard Space Flight Center, the Catholic University, the Air Force Geophysics Laboratory, New Mexico State University, and the Defense Advance 
Research Projects Agency (DARPA) Nuclear Monitoring Office. The Experiment utilized a nitrogen cooled detector to determine the intensity of gamma radiation emitted from the Supernova.

The experiment was launched from Williams Field near McMurdo Station, Antarctica on January 8, 1988 The helium-filled, 11.6 million cubic foot balloon reached an altitude of 22 miles and stayed afloat for three days. The PV power supply, figure 22, consisted of 600 Watts of Solarex SX-LITE modules configured into two 28 volt strings. Eight Polar Products controllers, 320 amp-hours of Eagle-Picher silver-zinc secondary batteries, provided power to a continuous load of 12 amps at 28 volts. The system worked without failure and the batteries were recovered fully charged.

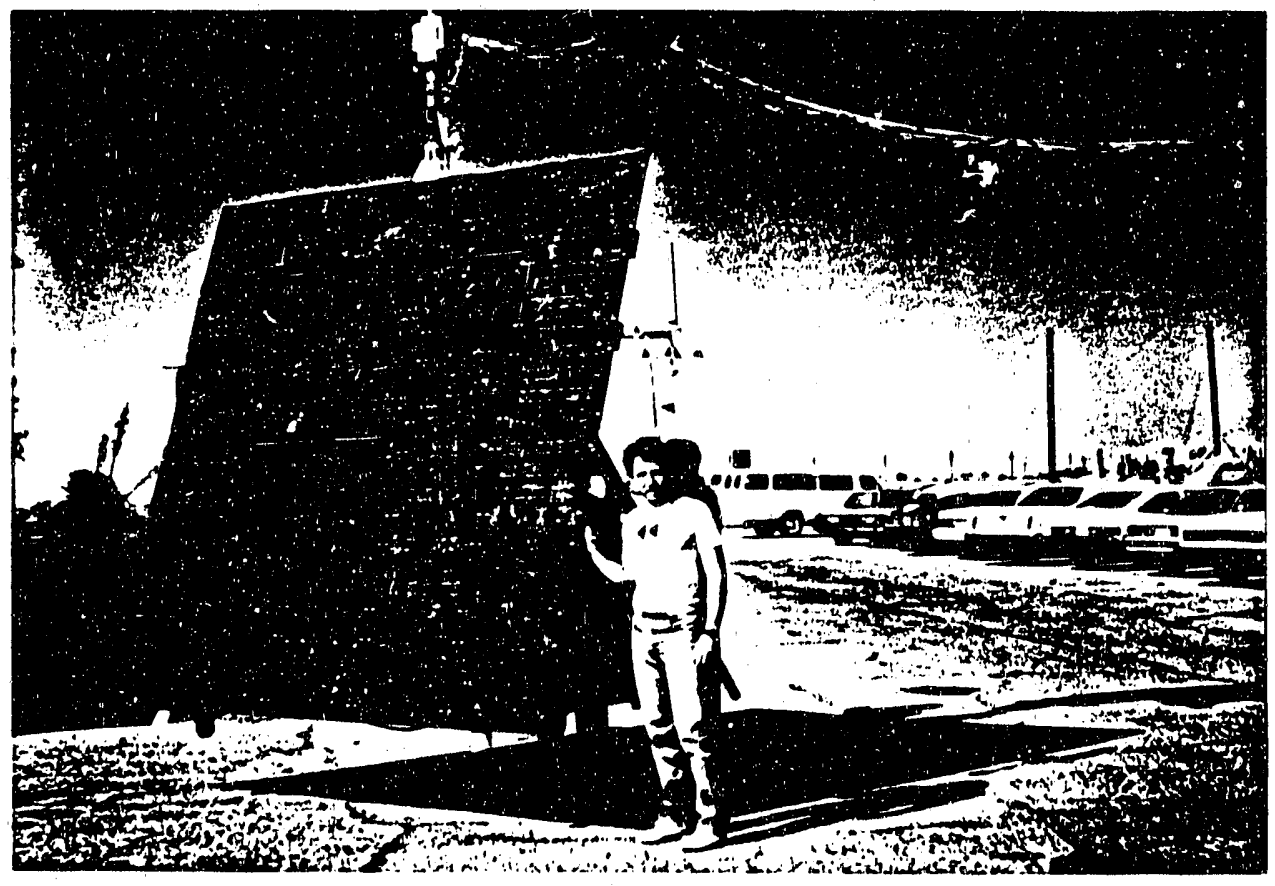

Figure 22. PV Power Supply for Balloon. 
Some module damage occurred when the array temperature exceeded $100^{\circ} \mathrm{C}$. This was characterized by de-lamination of the polymer superstrate. A comparison of before and after I-V curves indicated there was no change in the electrical output of the heat damaged modules.

\subsection{PVUSA Data Acquisition System}

The SWRES designed, built, and installed the data acquisition system for the Photovoltaics For Utility Scale Applications (PVUSA) project in Davis, California. The system provided is simple and reliable. Figure 23 shows the basic system. The initial configuration will have 8 individual dataloggers (expandable to 22) connected to the central data acquisition computers.

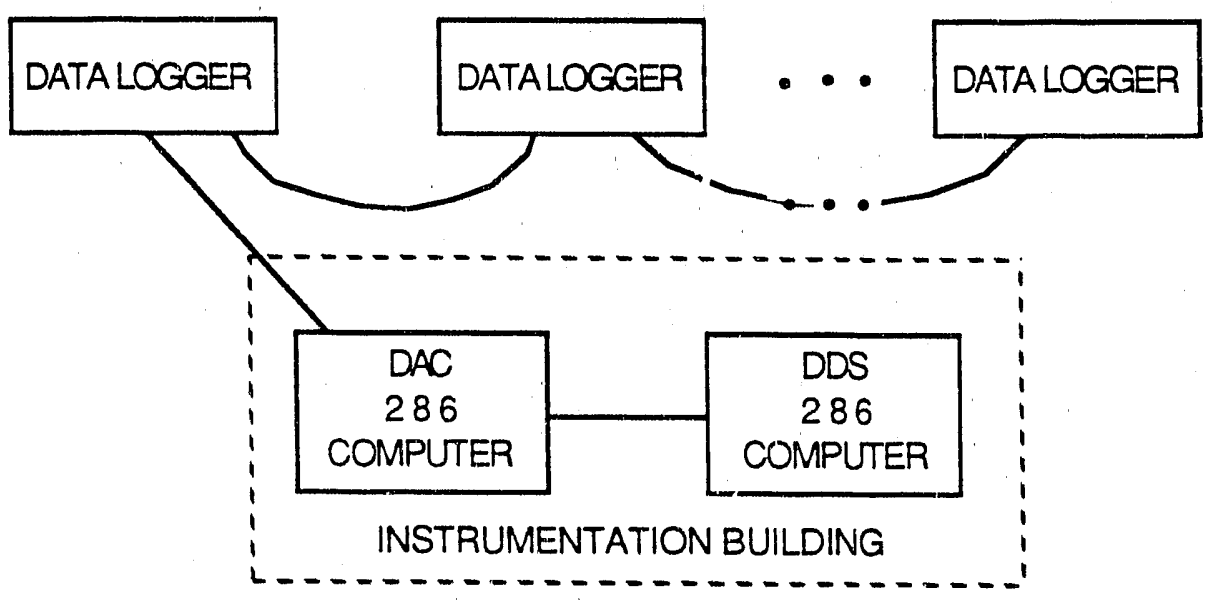

Figure 23. Basic System Configuration.

Two identical computers are used. The primary data acquisition control computer or DAC is dedicated to gathering and storing the data from the remote dataloggers located at each PV system. Computing tasks such as data display, 
printing, plotting, and transfer functions are performed by the secondary data display system (DDS) computer without interfering with continuous data acquisition.

The Model 2.1XL Micrologger, manufactured by Campbell Scientific, Inc., is used at each PV system. This unit samples the analog and digital signals every 5 seconds and averages them over a 10-minute interval. As new PV systems are installed additional Microloggers will be installed with only minor software changes in the control computers.

\subsection{TDI/GNERI Joint Venture}

In April 1988, Dr. V. Risser visited the Gansu Natural Energy Research Institute (GNERI) China as a visiting lecturer under a United Nations program. A proposal was written for a project to introduce photovoltaic systems into western China. The proposal was accepted and will be co-funded by the United Nations Development Program and the government of Chini PV systems will be installed in western China for various applications including water pumping, residential, and communications. Also, a test support facility will be designed and built at the GNERI facilities. The SWRES will be involved with several aspects of the multiyear program.

- Trainin $r$ of Chinese engineers at the SWRES. PV system sizing, design, engineering, installation, operation and maintenance will be covered. Chinese engineers will spend up to six months at the SWRES working with our engineers.

- Training of Chinese technicians. Two 4 week training courses will be held in China for technicians that will be installing and maintaining the PV systems. There will be systems in many of the weitern provinces and in Tibet. Technicians will be invited to Lanzhou for these training courses. 
- Data acquisition system development. While the first group of Chinese engineers are at the SWRES, we will design and build a data acquisition system that will be used at their experiment station. This approach will allow the engineers to become acquainted with the DJAS before they install and operate it in China.

- $\quad$ PV system test equipment will be built or obtained while the Chinese engineers are at the SWRES. This will give them familiarity with the hardware before they use it in China.

\subsection{Point Design Handbook}

The SWRES staff completed a stand-alone PV system manual Stand-Alone Photovoltaic Systems--A Handbook of Recommended Design Practices for Sandia's Design Assistance Center (DAC) in 1988. Five small businesses joined forces with the DAC and us to ensure realism in this handbook. The handbook has been well received and two printings have been done. A Spanish language version is planned.

\subsection{Data Acquisition System Design Manual}

The SWRES engineering staff prepared a manual for EPRI titler Data Acquisition Systems - Planning and Installation that guides the reader through planning, specifying, and installing a small data acquisition system. The information in the manual is based on experience gained at the SWRES in instrumenting PV systems and associated weather stations. Photographs and graphics are used to explain certain aspects of system installation. The manual specifically discusses the various considerations in setting up a data acquisition system to monitor a utility connected photovoltaic system, and a specific data acquisition system is discussed, including a datalogger, sensors, and software. 
A Campbell Scientific 21X datalogger is used in the example system, but the manual is also useful to those who wish to use other equipment. A software package for archiving data and performing quality assurance is included with the manual. The appendices include a complete set of schematics for the example data acquisition system and product literature for a variety of sensors and dataloggers. The manual is contained in a three ring binder so the the user can irisert information and brochures that are specific to his or her system. 

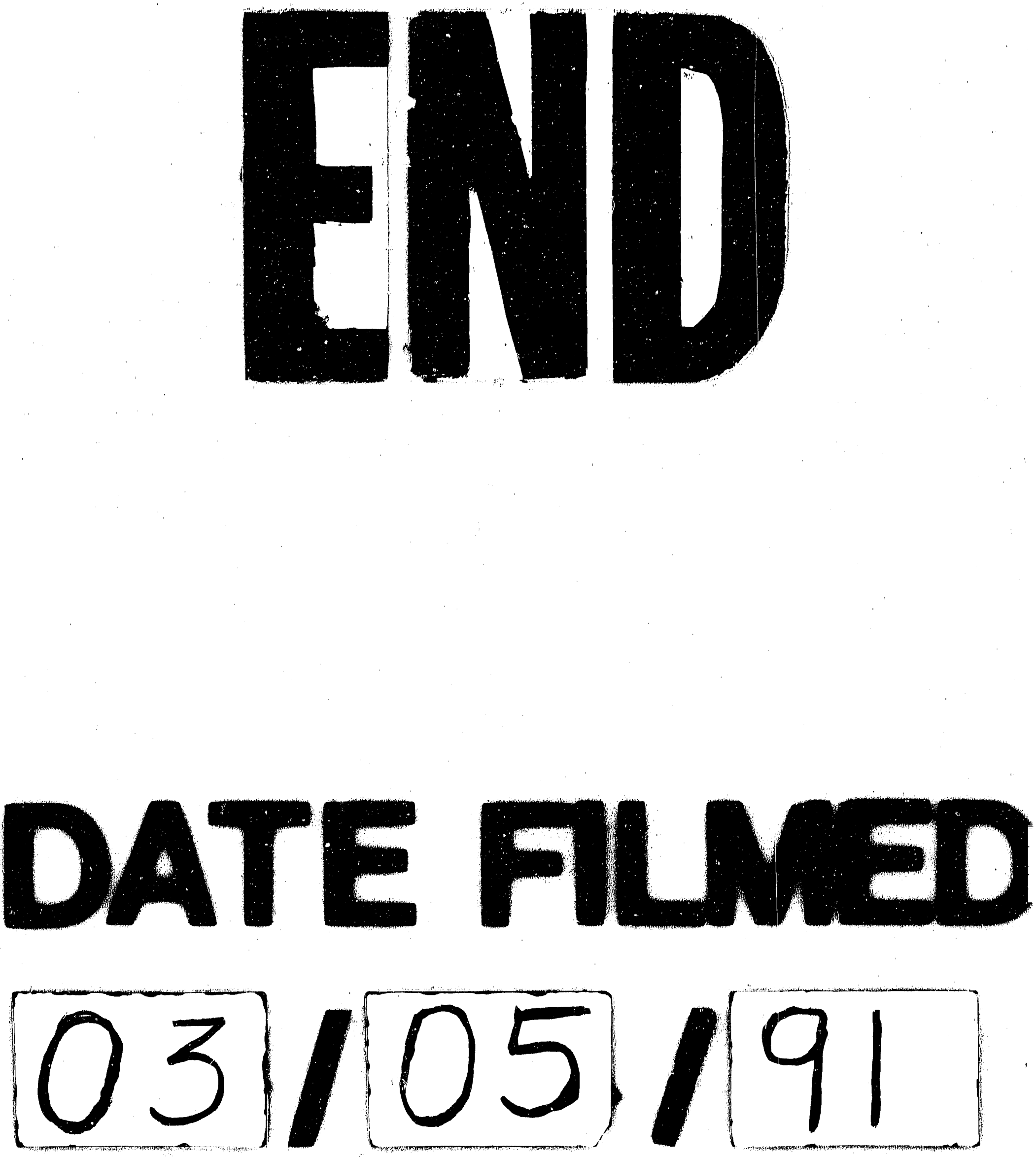
